\title{
Asian cave-adapted diplurans, with the description of two new genera and four new species (Arthropoda, Hexapoda, Entognatha)
}

\author{
Alberto SENDRA ${ }^{1}$, Ana KOMERIČKI ${ }^{2}, J_{\text {Josiane LIPS }}^{3}$, Yunxia LUAN ${ }^{4}$, Jesús SELFA $^{5} \&$ \\ Alberto JIMÉNEZ-VALVERDE ${ }^{6}$ \\ ${ }^{1}$ Colecciones Entomológicas Torres-Sala, Servei de Patrimoni Històric, \\ Ajuntamment de València, València, Spain. \\ ${ }^{2}$ Croatian Biospeleological Society, Rooseveltov trg 6, 10000 Zagreb, Croatia. \\ ${ }^{3}$ Fédération française de Spéléologie, Commission scientifique, \\ Groupe d'Étude de Biospéologie, France. \\ ${ }^{4}$ Guangdong Provincial Key Laboratory of Insect Developmental Biology and Applied Technology, \\ Institute of Insect Science and Technology, School of Life Sciences, \\ South China Normal University, Guangzhou, China. \\ ${ }^{5}$ Departament de Zoologia, Laboratori de Ìnvestigació d'Entomologia, Universitat de València, \\ Carrer Dr Moliner s/n, 46100 Burjassot, València, Spain.
}

${ }^{6}$ Research Team on Soil Biology and Subterranean Ecosystems, Department of Life Sciences, Faculty of Science, University of Alclá (UAH), A.P. 20, Campus Universitario, 28805, Alcalá de Henares, Madrid, Spain.

*Corresponding author: alberto.sendra@uv.es

${ }^{2}$ Email: ana.komericki@hbsd.hr

${ }^{3}$ Email: josiane.lips@free.fr

${ }^{4}$ Email: yxluan@scnu.edu.cn

${ }^{5}$ Email: jesus.selfa@uv.es

${ }^{6}$ Email: alberto.jimenez@uah.es

\footnotetext{
${ }^{1}$ urn:lsid:zoobank.org:author:11636BAE-AE66-4898-A7C8-35B329E7E3A8

${ }^{2}$ urn:1sid:zoobank.org:author:65524F03-93E0-4782-AB01-2BD3BD0CEE0D

${ }^{3}$ urn:1sid:zoobank.org:author:1B04F1FC-44EC-41D2-8CC6-0B4B52B8C303

${ }^{4}$ urn:1sid:zoobank.org:author:8E221271-5EE9-47FF-9A1B-C6299C8B608D

${ }^{5}$ urn:1sid:zoobank.org:author:C01B4FA6-6C5C-4DDF-A114-2B06D8FE4D20

${ }^{6}$ urn:1sid:zoobank.org:author:E31ADC69-98EE-46CB-87E2-5B27B53FF107
}

\begin{abstract}
Twenty-nine specimens of Diplura collected from eight caves in China and Myanmar contain two new genera, Hubeicampa Sendra \& Lips gen. nov. and Mueggejapyx Sendra \& Komerički gen. nov., as well as four new species, Anisuracampa ywangana Sendra \& Komerički sp. nov., Hubeicampa melissa Sendra \& Lips gen. et sp. nov., Pacificampa wudonghuii Sendra sp. nov. and Mueggejapyx brehieri Sendra \& Komerički gen. et sp. nov. These cave-adapted taxa showcase an impressive diversity in morphological adaptation (troglomorphy) to cave ecosystems. Their sensorial equipment, setae and receptors in the cupuliform organ have unique forms (H. melissa gen. et sp. nov.), as well as the pretarsus sticky surface (A. ywangana sp. nov. and H. melissa gen. et sp. nov.). Recent contributions
\end{abstract}


on Asian diplurans, together with the taxonomic novelties shown in the present study, highlight the biogeographical importance of the Asian biodiversity. Asia is revealed as a continent with vast karst regions still waiting to be explored and new dipluran species waiting to be discovered.

Keywords. Campodeidae, Japygidae, Asia, caves, biogeography, troglomorphy.

Sendra A., Komerički A., Lips J., Luan Y., Selfa J. \& Jiménez-Valverde A. 2021. Asian cave-adapted diplurans, with the description of two new genera and four new species (Arthropoda, Hexapoda, Entognatha). European Journal of Taxonomy 731: 1-46. https://doi.org/10.5852/ejt.2021.731.1199

\section{Introduction}

Asia is the largest continent and has $30 \%$ of the Earth's total land surface, in which karst landscapes with caves occupy vast regions; two million square kilometers in China (Juberthie \& Decu 2001). A huge number of these caves remain unexplored from a biospeleological perspective (Juberthie \& Decu 2001). Over the last two decades, studies of Asian caves have revealed a wide diversity of highly caveadapted species in Collembola, Carabidae, Diplopoda, fishes, and other zoological taxa (Ma \& Zhao 2012; Golovatch 2015; Tian et al. 2016; Deharveng \& Bedos 2018). Among these amazing discoveries are also diplurans (Sendra et al. 2017a, 2020; Sendra \& Deharveng 2020).

Diplura Börner, 1904, an order of basal hexapods, has many species living in cryptic hypogean habitats worldwide, except in polar and permafrost regions (Condé 1956; Sendra 2015). Of the approximately 1000 known extant species, $15 \%$ dwell in caves only. However, the presence of diplurans in Asian cave ecosystems is still poorly studied, where only seventeen species from ten genera have been described. Our current knowledge dates back to the middle of the last century with three monotypic genera: two Campodeidae Lubbock, 1873, Vandelicampa Condé, 1955 in Lebanon and Simlacampa Condé, 1956 in Pendjab, northwest India; and one Japygidae Haliday, 1864, Kohjapyx Pagés, 1962, from a cave in Afghanistan. In addition, one species of the most widespread japygid genus Burmjapyx Silvestri, 1930, Burmjapyx inferus (Carpenter, 1932) was found in Malaysia (Pagés 1977). In the last decades of the $20^{\text {th }}$ century, Chevrizov (1978) described Pacificampa Chevrizov, 1978 and Plutocampa Chevrizov, 1978 from caves in the Far East of Russia whereas Condé $(1992,1993)$ proposed Plusiocampa lipsae Condé, 1993 from a cave in East China and Lepidocampa hypogaea Condé, 1992 from seven caves in Sulawesi. Recently, Sendra et al. $(2017 \mathrm{a}, 2018)$ described two new species of Pacificampa from Japanese caves as well as one monotypic genus, Turkmenocampa Sendra \& Stoev, 2017, from a cave in Central Asia. Most recently, Sendra \& Deharveng (2020) and Sendra et al. (2020) described a new genus, Whittencampa Sendra \& Deharveng, 2020, from caves in southern China and noted the presence of Plusiocampa (Plusiocampa) aff. schweitzeri Condé, 1947 in a cave in the Anatolian peninsula and Plusiocampa (Plusiocampa) aff. dublanskii Sendra \& Turbanov, 2020 in a cave in the western Caucasus (Supp. file 1). In addition to these already described species, other undescribed forms have been mentioned in biospeleological literature. These include an undescribed form of Pacificampa from China, recorded not far from the known genus distribution (Ferguson 1997; Sendra et al. 2018), as well as the observation of cave-adapted diplurans in several Asiatic countries by Juberthie \& Decu (2001): japygids (Thailand) and campodeids (Vietnam).

Herein, we describe two remarkable new highly cave-adapted genera and four new species of Diplura from caves in a few karst areas in the Far East of Russia, central and northeastern China and Myanmar. These new taxa provide another piece of the puzzle to understand the Asian dipluran fauna and to further our knowledge of the evolution of cave ecosystems. 


\section{Material and methods}

Specimens were collected directly by hand and stored in $70-75 \%$ ethanol, then washed with distilled water and mounted on slides in Marc André II solution. Mounted specimens were examined with a phase-contrast optical microscope (Leica DMLS). The illustrations were made with a drawing tube and measurements were taken with an ocular micrometer. For measuring the body length, the specimens were mounted in toto and measured from the base of the frontal process distal macrosetae to the abdomen's supra-anal valve. Two specimens, coated with palladium-gold, were used for SEM (Hitachi S-4800) photography and for measuring the sensilla.

The morphological descriptions and abbreviations follow Condé (1956). For Campodeidae, we use the term gouge sensilla for the concave-convexly shaped sensilla on the antennae (Bareth \& Condé 1981). For the position of macrosetae, we adopt the abbreviations of Condé (1956): $m a=$ medial-anterior; $l a=$ lateral-anterior; $l p=$ lateral-posterior; post $=$ posterior.

Terminology for the species is from Smith (1962) and Pagés $(1953,1984)$ : A = macrosetae in A position; $\mathrm{B}=$ macrosetae in $\mathrm{B}$ position; $\mathrm{C}=$ macrosetae in $\mathrm{C}$ position; $\mathrm{D}=$ macrosetae in $\mathrm{D}$ position; $\mathrm{L}=$ macrosetae in $\mathrm{L}$ position; $\mathrm{M}=$ larger macrosetae of the body set in reinforced setal sockets; $\mathrm{ms}=$ microsetae or minute setae visible only under high magnification and always set in simple setal sockets; $\mathrm{P}=$ macrosetae in $\mathrm{P}$ position; $\mathrm{sM}=$ medium-sized sub-macrosetae usually set in simple setal sockets; $\mathrm{V}$ $=$ macrosetae in $\mathrm{V}$ position; friction setae $=$ microsetae with large sockets that occurs in groups where the body integument folds or moves upon itself and would perhaps otherwise cause abrasion. For the specific terminology of buccal pieces see Pagés (1964) and for thoracic sclerites see Pagés (1964) and Barlet \& Carpentier (1962). For the cercal chaetotaxy we have used Muegge \& Bernard (1990).

The holotype, paratypes and other studied specimens are kept at the following institutions:

Coll. AS = private collection of Alberto Sendra, València, Spain

NEIGAE = Northeast Institute of Geography and Agroecology, Changchun, China

MZB $(\mathrm{MCNB})=$ Museu de Ciències Naturals de Barcelona, Spain

ZMMU $\quad=$ Zoological Museum of the Moscow Lomonosov State University, Russia

\section{Results}

Class Entognatha Lubbock, 1870

Subphylum Hexapoda Latreille, 1825

Order Diplura Börner, 1904

Suborder Rhabdura Cook, 1896

Family Campodeidae Lubbock, 1873

Subfamily Plusiocampinae Plact, 1957

Genus Anisuracampa Xie \& Yang, 1991

Diagnosis (modified and improved from original diagnosis by Xie \& Yang 1991)

Mesonotum and metanotum with 1+1 medial anterior, no or $2+2$ lateral anterior, and $2+2$ to $4+4$ lateral posterior macrosetae. Two to three dorsal macrosetae on metathoracic legs. Elbowed claws ventrally with long spiniform formations with apparently lateral crests. Laminar pretarsus lateral processes with long, broad barbs. Urotergites with $4+4-5+5$ posterior macrosetae on urotergites V-VII. Eighth urosternite with 1+1 macrosetae. First urosternite with non-glandular setae bearing coniform or subtrapezoidal appendages. 
Anisuracampa ywangana Sendra \& Komerički sp. nov. urn:1sid:zoobank.org:act:511F81B5-6CB2-4A98-AB3E-11AF72205A26

Figs 1, 3-19; Tables 1-2; Supp. file 2

\section{Etymology}

This species is named after the important karst region Ywangan in Myanmar, the location of Win Twin Cave (Figs 1, 3-4).

\section{Type material}

\section{Holotype}

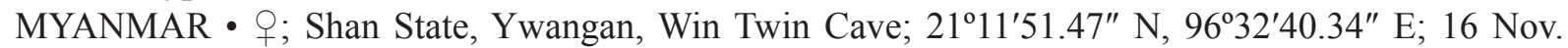
2018; Aung Lin leg.; labelled "holotype"; MZB (MCNB) 2020-1152.

\section{Paratypes}

MYANMAR • 1 q; same collection data as for holotype; labelled "paratype-H1"; MZB (MCNB) 2020$0620 \bullet 1$ +, 1 o, 1 juvenile; same collection data as for holotype; 8 May 2018; labelled "paratype-H2", "paratype-M", "paratype-J”; MZB (MCNB) 2020-1153, MZB (MCNB) 2020-1155, MZB (MCNB) 2020-1154 .

\section{Other material examined}

MYANMAR -2 specs; same collection data as for the holotype; 8 May 2018; mounted on two separate aluminium stages and coated with palladium-gold; Coll. AS.

\section{Description}

Body. Length is $4.3-6.0 \mathrm{~mm}(\mathrm{n}=4)$ in adults and $2.6 \mathrm{~mm}$ in one juvenile (Table 1). The epicuticle is smooth under optical microscope but reticulated at higher magnification, showing irregular polygonal structures of variable sizes (Fig. 11). Body with long smooth clothing setae.

HeAd. Two complete and intact antennae in holotype and paratype-M with 35 antennomeres each, whereas paratype-J (juvenile) has 38 antennomeres. The antennae are similar to length of body (Table 1 ), with medial antennomeres $2 \times$ as long as wide but apical antennomeres $1 \frac{1 / 2}{} \times$ as long as wide. Cupuliform organ with up to 17 spheroidal olfactory chemoreceptors arranged in two uneven concentric circles; each chemoreceptor forms a complex structure of multi-perforated folds with one distinguishing crown of fringes a surrounding central column. Each of these structures is inside a polygonal cell (Figs 5-6). Distal and central antennomeres with three whorls of distal barbed macrosetae and 5-6 scattered whorls of smooth setae in addition to single distal whorl of up to 14 gouge sensilla of 24-28 $\mu \mathrm{m}$ length (Figs 7-8) that are more abundant on dorsal side of antennomere. Proximal antennomeres with typical trichobothria, plus small bacilliform sensillum on third antennomere in ventral position. Round protrusion of frontal process covered with one anterior macroseta and two or three posterior macrosetae (Fig. 10). Three macrosetae along each side of insertion line of antennomere and $x$ setae with thin distal barbs; length ratios of $a / i / p / x, 45 / 57 / 56 / 65$, respectively, in paratype-H2. Labial palps large and suboval, each with bacilliform latero-external sensillum, two guard setae, up to 18 normal setae and up to 140 neuroglandular setae.

ThORAX. Thoracic macrosetae distribution (Figs 9, 11) have pronotum with 1+1 $m a, 1+1$ la, 2+2 lp2,3 macrosetae; mesonotum with $1+1 m a, 2+2 l a$ and 4+4 lp $1-4$ macrosetae; and metanotum with $1+1 m a$, $2+2 l a$ and 3+3 lp $1-3$ macrosetae. All macrosetae long and with thin barbs along basal half to twothirds of each seta; marginal setae barbed and longer than clothing setae. Legs elongated, metathoracic legs reach end of abdomen in adults or overpass it in juvenile. Tibia always longer than femur or tarsus 
(Table 1). Each femur III with three or, less frequently, two long dorsal macrosetae with distal barbs ( $0.25 \mathrm{~mm}$ in $0.62 \mathrm{~mm}$ femur of paratype-H1) (femora I-II with one to three long dorsal macrosetae). Calcars covered with thin abundant barbs all over. Tibiae I-III usually with two short, completely barbed ventral macrosetae, occasionally just one. Each tibia with two rows of ventral barbed setae almost from base and scattered throughout with thin, long setiform sensilla. Three well-barbed dorsal distal tarsal setae longer than rest of tarsal setae. Subequal claws with lateral expansion in crest; basal and ventral
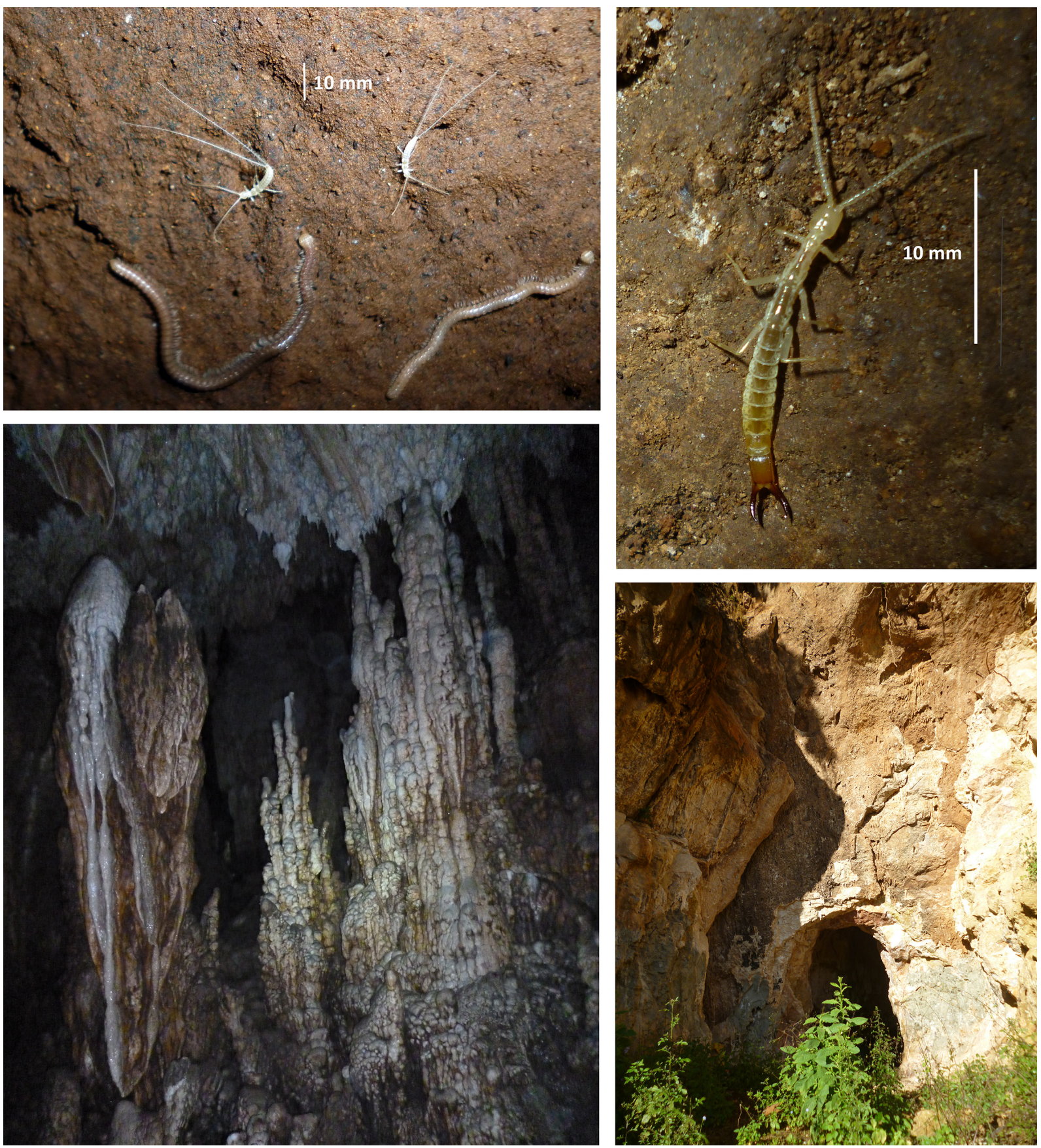

Figs 1-4. Cave-adapted diplurans from Win Tin Twin Cave, Ywangan karst, Shan State, Myanmar. 1. Anisuracampa ywangana Sendra \& Komerički sp. nov., with Diplopoda at $300 \mathrm{~m}$ from the entrance. 2. Mueggejapyx brehieri Sendra \& Komerički gen. et sp. nov. at the same site. 3. Speleothems in the main passage of the cave. 4. Entrance to the cave. (Photographs: Ana Komerički). 
Table 1. Anisuracampa ywangana Sendra \& Komerički sp. nov., length of the body, antennae and metathoracic leg, including their segments, and cerci (units in $\mathrm{mm}$ ) as well as number of antennomeres.

\begin{tabular}{|c|c|c|c|c|c|c|c|c|c|}
\hline \multirow{2}{*}{ Specimen } & \multirow{2}{*}{$\begin{array}{l}\text { Body } \\
\text { length }\end{array}$} & \multirow{2}{*}{$\begin{array}{c}\text { Antennae } \\
\text { length }\end{array}$} & \multirow{2}{*}{$\begin{array}{c}\text { Antenno- } \\
\text { meres }\end{array}$} & \multicolumn{5}{|c|}{ Segment length of the metathoracic leg } & \multirow{2}{*}{$\begin{array}{c}\text { Total } \\
\text { metathoracic } \\
\text { length }\end{array}$} \\
\hline & & & & coxa & trochanter & femur & tibia & tarsus & \\
\hline $\begin{array}{l}\text { Holotype } \\
\text { (MZB (MCNB) } \\
2020-1152)\end{array}$ & 6.0 & - & - & 0.25 & 0.25 & 0.90 & 1.14 & 0.78 & 3.32 \\
\hline $\begin{array}{l}\text { Paratype-H2 } \\
\text { (MZB (MCNB) } \\
2020-1153 \text { ) }\end{array}$ & 5.8 & 5.8 & 35 & 0.23 & 0.20 & 0.90 & 1.02 & 0.73 & 3.08 \\
\hline $\begin{array}{l}\text { Paratype-M } \\
\text { (MZB (MCNB) } \\
2020-1154)\end{array}$ & 4.4 & 4.6 & 35 & 0.22 & 0.20 & 0.57 & 0.85 & 0.60 & 2.44 \\
\hline $\begin{array}{l}\text { Paratype-H1 } \\
\text { (MZB (MCNB) } \\
2020-0620)\end{array}$ & 4.3 & - & - & 0.21 & 0.20 & 0.62 & 0.78 & 0.62 & 2.43 \\
\hline $\begin{array}{l}\text { Paratype-J } \\
\text { (MZB (MCNB) } \\
2020-1155)\end{array}$ & 2.6 & 2.8 & 37 & 0.14 & 0.14 & 0.40 & 0.51 & 0.42 & 1.61 \\
\hline
\end{tabular}

portion of claws covered with short to long spiniform formations. Laminar pretarsus of lateral processes sharply curved with what apparently looks like thin fringes under optical microscope, but under SEM seen as narrow laminar expansions (Figs 12-15).

AвDOMEN. Distribution of macrosetae on tergites with $1+1$ post 1 on I-III; $1+1$ post 1 to $3+3$ post $1-3$ on IV, $4+4$ post $1-4$ and $1+1$ la on V, $5+5$ post $1-5$ or $6+6$ post $1-6$ and $1+1$ la on VI-VII; $7+7$ post on VIII; and $8+8$ or $9+9$ post macrosetae on IX abdominal segment. All tergal abdominal macrosetae long and barbed along distal half to four-fifths. Urosternite I has 7+7 macrosetae (Figs 16-17); while urosternites II to VII with 5+5 macrosetae; and urosternite VIII with 1+1 macrosetae; urosternal macrosetae of medium size and barbed along distal half. Stylus with short apical seta with small barbs, and each subapical seta completely covered with barbs and with short, barbed ventromedial seta (Figs 18-19). One intact cercus $2.4 \times$ body length and with 14 primary articles (Table 2 ). Article length increases from proximal to distal articles; covered with long thin macrosetae, with distal barbs, and less abundant long, thin setae. Each primary article with whorl of shorter thin plumose setae at distal position.

SeCONDARY SEX CHARACTERs. Female urosternite I with enlarged subcylindrical appendages, each bearing up to 60 ventral glandular $a 2$ setae proximally and apical field of up to 28 glandular $a 1$ setae (Figs 16-17). Male with similar appendages with two fields of glandular setae (19 $a 2$ and $27 a 1$ ) in one appendage of male paratype. Spermatozoid fascicles small, $0.04 \mathrm{~mm}$ in diameter, and formed by undistinguishable filament of spermatozoids in spiral.

\section{Taxonomic affinities}

Anisuracampa was proposed for a soil-dwelling species, Anisuracampa suoxiensis Xie \& Yang, 1990 from Hunan Province in southeastern China. As a plusiocampine genus, Anisuracampa is characterized by the laminar pretarsus but with the lateral processes with long barbs and weakly developed lateral crests (Figs 12-15) (see Xie \& Yang 1991: fig. 34). In addition to this trait, Anisuracampa has two or three dorsal femoral macrosetae and 1+1 macrosetae on the eighth urosternite. All of these characters are present in A. ywangana sp. nov., a cave-adapted species from the Win Twin Cave in eastern Myanmar. 
Table 2. Anisuracampa ywangana Sendra \& Komerički sp. nov., paratype MZB (MCNB) 2020-1153, length of cercal articles and total length (units in $\mathrm{mm}$ ), including number of articles of the cercus, basal article included, and division of basal article in secondary articles.

\begin{tabular}{cccccccccccccccccccccc}
\hline $\begin{array}{c}\text { Division- } \\
\text { basal article }\end{array}$ & $\begin{array}{c}\text { Basal } \\
\text { article }\end{array}$ & $\mathbf{1}^{\text {st }}$ & $\mathbf{2}^{\text {nd }}$ & $\mathbf{3}^{\text {rd }}$ & $\mathbf{4}^{\text {th }}$ & $\mathbf{5}^{\text {th }}$ & $\mathbf{6}^{\text {th }}$ & $\mathbf{7}^{\text {th }}$ & $\mathbf{8}^{\text {th }}$ & $\mathbf{9}^{\text {th }}$ & $\mathbf{1 0}^{\text {th }}$ & $\mathbf{1 1}^{\text {th }}$ & $\mathbf{1 2}^{\text {th }}$ & $\mathbf{1 3}^{\text {th }}$ & $\mathbf{1 4}^{\text {th }}$ & $\begin{array}{c}\text { Total } \\
\text { cercus }\end{array}$ & $\begin{array}{c}\text { Number } \\
\text { of } \\
\text { articles }\end{array}$ \\
\hline 3 & 1.1 & 0.39 & 0.45 & 0.50 & 0.55 & 0.65 & 0.75 & 0.83 & 0.92 & 0.94 & 1.20 & 1.44 & 1.65 & 1.67 & 1.64 & 14.68 & 15 \\
\hline
\end{tabular}

Therefore, these morphological similarities together with the congruent geographical distribution in Southeast Asia are considered sufficient reason to place this new species in Anisuracampa. However, A. ywangana sp. nov. differs from A. suoxiensis in several characters besides the traits related to adaptations to cave ecosystems. Anisuracampa ywangana sp. nov. has $4+4$ lateral posterior macrosetae on the mesonotum (Fig. 9) $(2+2$ in A. suoxiensis), $3+3$ lateral posterior and $2+2$ lateral anterior macrosetae on the metanotum $(2+2$ lateral posterior and no lateral anterior macrosetae in A. suoxiensis $)$ and $5+5$ posterior and $1+1$ lateral anterior macrosetae on urotergites V-VII $(4+4$ posterior and no lateral anterior macrosetae in A. suoxiensis). Regarding the new species' cave-adapted features, it has a larger body and longer appendages at least double the size of those of $A$. suoxiensis, with 30-35 antennomeres in A. ywangana sp. nov. (24 in A. suoxiensis). It is impossible to compare other useful taxonomical
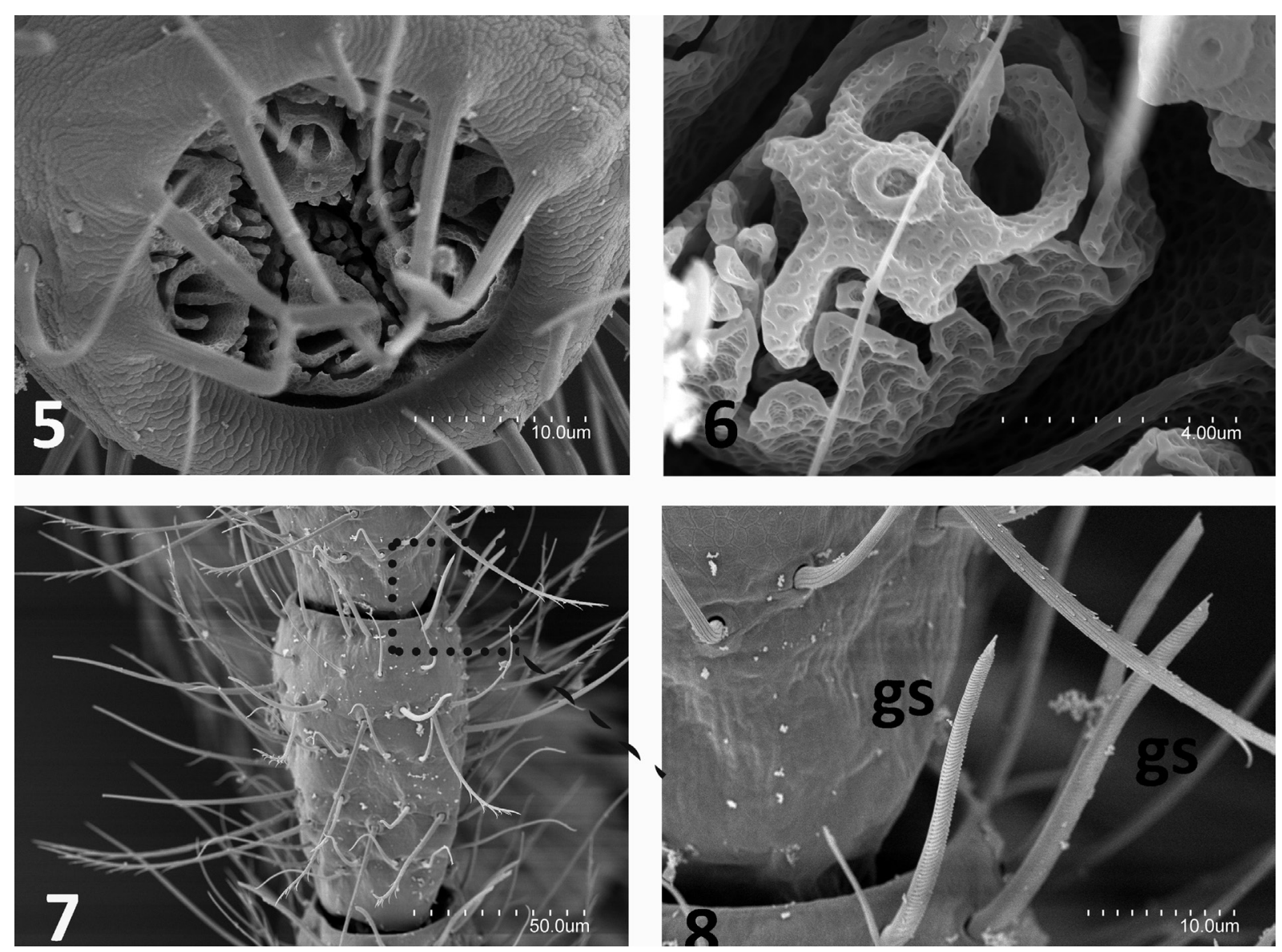

Figs 5-8. Anisuracampa ywangana Sendra \& Komerički sp. nov. 5. Apical view of last antennomere. 6. Olfactory chemoreceptor of the cupuliform organ. 7. Central antennemeres. 8. Lateral distal medial antenomere with gouge sensilla (gs). 


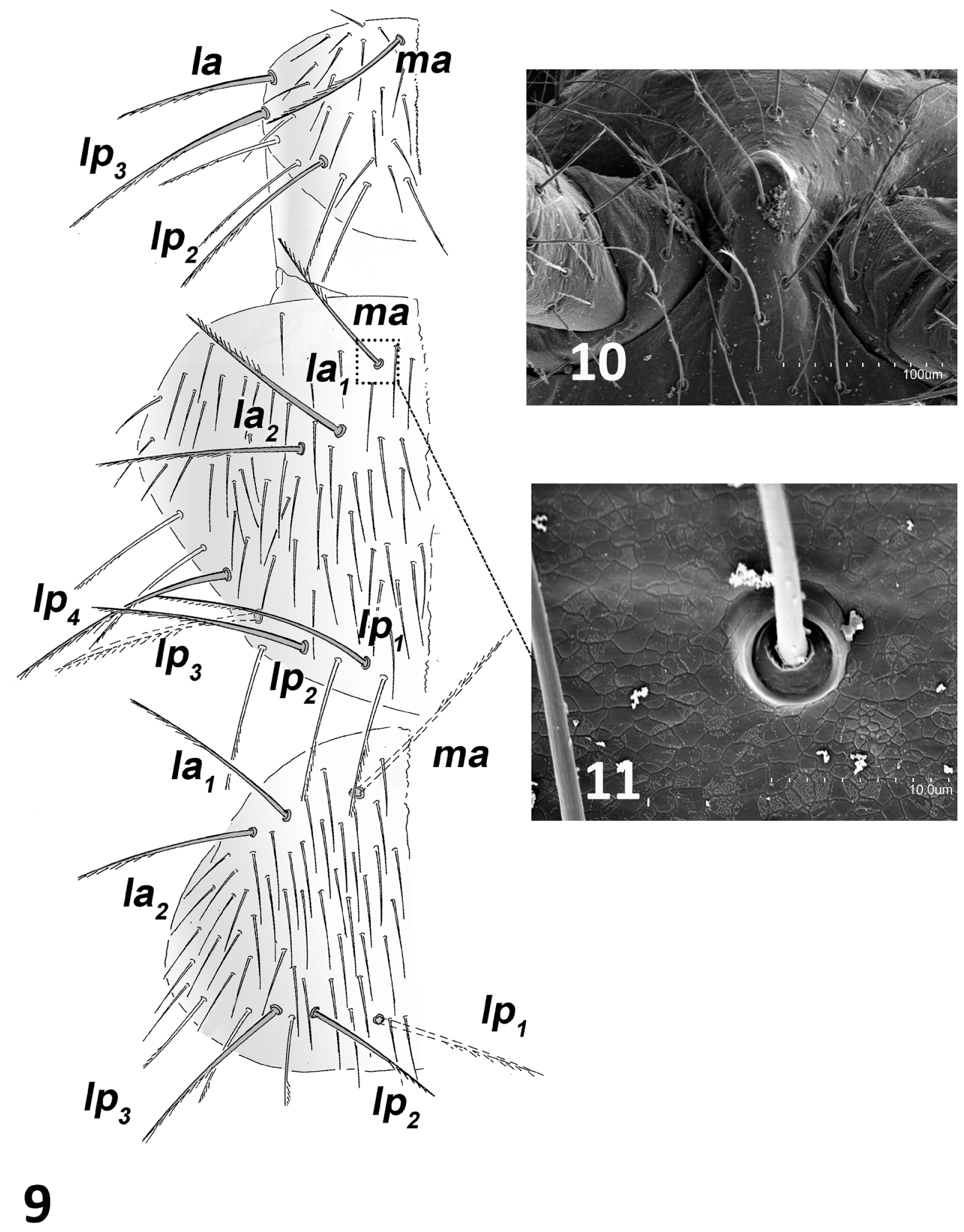

Figs 9-11. Anisuracampa ywangana Sendra \& Komerički sp. nov., holotype (MZB (MCNAB) 20201152) 9. Pronotum, mesonotum, and metanotum, left side. 10. Frontal process. 11. Detail of the base of medial anterior mesonotal macroseta. 
characteristics mentioned in the description of A. ywangana sp. nov. with A. suoxiensis as the former was described using SEM, whereas the latter was described under optical observations with a brief diagnosis and the type material of A. suoxiensis is not available for study.

\section{Remarks}

Anisuracampa ywangana sp. nov. was observed and collected walking on the Win Twin cave floor and boulders, approximately $300 \mathrm{~m}$ from the entrance, and on the wet flowstone in a vast chamber (Figs 1-3; Supp. file 2). The Win Twin cave is located within a large karst area referred to as Ywangan karst, which is situated in the western part of the Shan plateau, approximately $10 \mathrm{~km}$ northeast of Ywangan Township and $15 \mathrm{~km}$ east of the Panlaung Pyadalin Wildlife Sanctuary. The cave has only been discovered recently and is currently under tourist development by the local community. It has not been fully surveyed and approximately only the first $400 \mathrm{~m}$ were explored during the collection of the type material. The cave itself is large, with numerous chambers, and its entrance was enlarged by mining (Fig. 4); after approximately $300 \mathrm{~m}$ into the main passage, it opens into a vast chamber filled with speleothems (Fig. 3), from which it again continues further by smaller, narrow passages opening into new chambers. At the bottom of the vast chamber, the oxygen level becomes too low for further exploration during the dry season (May), while by the end of the rainy season (November) it was possible to reach two further lower chambers

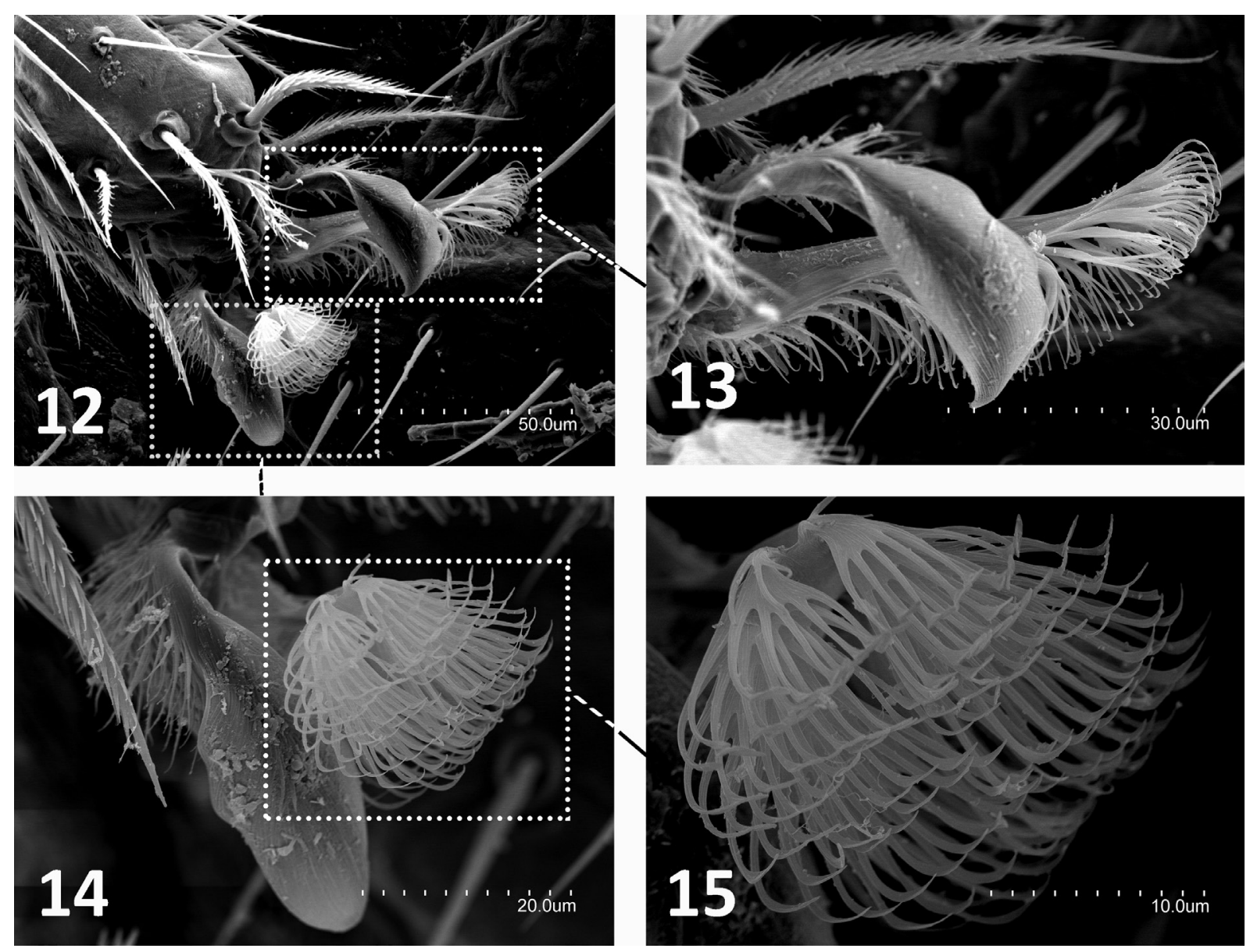

Figs 12-15. Anisuracampa ywangana Sendra \& Komerički sp. nov. 12. Pretarsus of metathoracic leg. 13. Posterior claw and its lateral processes of pretarsus. 14. Anterior claw and its lateral processes. 15. Detail of lateral processes. 
before the oxygen level became too low. No active water flow was observed, but sparse remains of particular organic matter are present and the air temperature recorded in May 2018 was $20.0^{\circ} \mathrm{C}$, while the sediment temperature was $19.6^{\circ} \mathrm{C}$ (unpublished data).
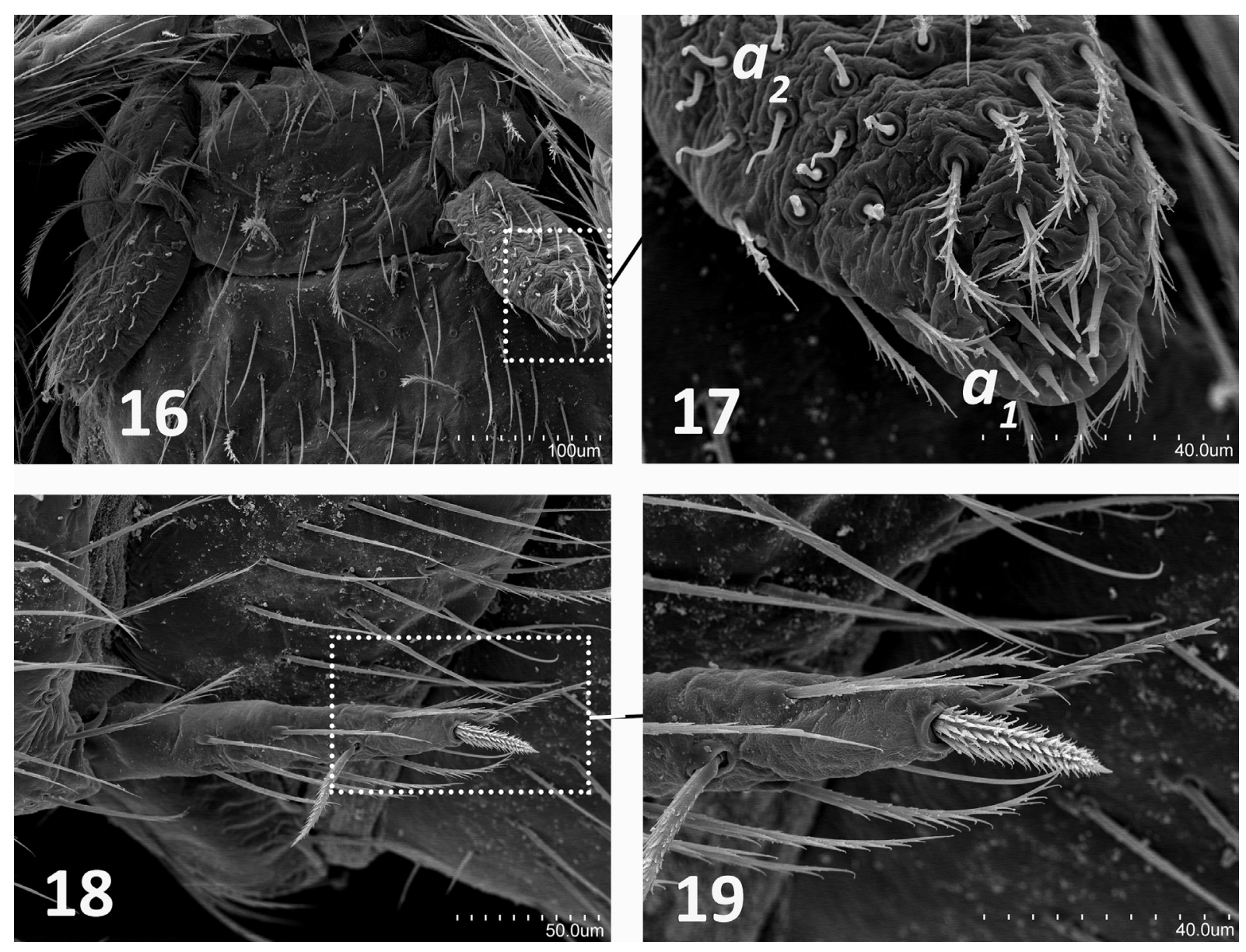

Figs 16-19. Anisuracampa ywangana Sendra \& Komerički sp. nov. 16. First urosternite in a female. 17. Detail of the appendage of the first urosternite in a female with glandular $a_{1}$ and $a_{2}$ setae. 18. Stylus of the lateral right side of the fifth urosternite. 19. Detail of the stylus of the lateral right side of the fifth urosternite.

Genus Hubeicampa Sendra \& Lips gen. nov. urn:1sid:zoobank.org:act:3992F636-8036-4734-ACA6-A4972A157D82

\section{Type species}

Hubeicampa lipsae (Condé, 1993) comb. nov.

Plusiocampa (Dydimocampa) lipsae Condé, 1993: 826, figs 2a-c.

\section{Diagnosis}

Dense pubescence of thin micro-barbs on setae. No more than $4+4$ macrosetae on pronotum, $3+3$ on mesonotum and $2+2$ on metanotum. One or two dorsal macrosetae on metathoracic femora and one or two on tibia. Subequal elbowed claws with lateral crests; basal and ventral portion of claws covered with very small, thin, spiniform formations that look pubescent under optical microscope. Laminar 
lateral processes of the pretarsus completely covered with dense micro-barbs. Urotergites V-VII with $3+3$ or $4+4$ posterior macrosetae and without lateral anterior macrosetae. Up to $12+12$ macrosetae on first urosternite, $4+4$ or $5+5$ macrosetae on second to seventh urosternites and $1+1$ macrosetae on eighth urosternite. First urosternite in males without glandular $g_{l}$ setae and appendages with glandular $a_{l}$ setae.

\section{Etymology}

The genus name refers to the Chinese province of Hubei where the first cave-adapted dipluran was described.

Hubeicampa melissa Sendra \& Lips gen. et sp. nov. urn:1sid:zoobank.org:act:E9EEC42A-21E5-43D8-B572-F4A6FD327323

Figs 20-48; Tables 3-4; Supp. file 3

\section{Etymology}

This species is dedicated to the memory of Mélissa Lagrède, a French caver and friend of Josiane Lips. Mélissa died in an accident inside a nearby cave on the very day the holotype of this new species was collected. She also collected a paratype in the same cave the day before she died. Noun in apposition.

\section{Type material}

\section{Holotype}

CHINA • P; Hubei, Banqiao, Grotte du $8^{\text {ième }}$ Ciel Baxian Dong; 8 Aug. 2009; Josiane Lips leg.; labelled "4168-holotype"; MZB (MCNB) 2020-1162.

\section{Paratypes}

CHINA • 1 क; ; same collection data as for holotype; labelled "4168-paratype"; MZB (MCNB) 2020-0621 • 1 q; same collection data as for holotype; Mélissa Lagrède leg.; 7 Aug. 2009; labelled "4158-paratype"; MZB (MCNB) 2020-1165.

\section{Other material examined}

CHINA -2 specs; same collection data as for holotype; mounted on two separate aluminium stages and coated with palladium-gold; Coll. AS • 1 §; Sichuan, Beichuan, Yin Keng Dong; 22 Aug. 2011; Josiane Lips leg.; Coll. AS • 2 우; Hubei, Banqiao, Tie He Cave; 11 Aug. 2006; Josiane Lips leg.; Coll. AS.

\section{Description}

Body. Length is $9 \mathrm{~mm}$ in holotype, $10.4 \mathrm{~mm}$ in female paratype and $6 \mathrm{~mm}$ in male paratype. Epicuticle smooth under optical microscope but reticulated at higher magnification, showing irregular polygonal structures of variable sizes (Figs 31-33). Body with apparently smooth clothing setae that in SEM have tiny expansions (micro-barbs) more abundant on other setae (macrosetae, marginal setae, style setae, tarsal setae and calcars) (Figs 26-29, 36, 42-45).

HEAD. In holotype, one complete and intact antennae with 49 antennomeres; antennae slightly longer than body length (Table 3 ), with medial antennomeres $3 \times$ as long as wide. Apical antennomere $4 \times$ as long as wide, with irregular cupuliform organ containing ramiform, net-like complex with numerous perforations, occupying $1 / 10$ of distal portion (Figs 20-21, 23). Distal and central antennomeres with two whorls of micro-barbed macrosetae (Figs 26-29); in addition, these have single distal whorl of up to $8-10$ thin long gouge sensilla of $85-95 \mu \mathrm{m}$ in length (Figs 22, 24), among them one small coniform sensillum (10 $\mu \mathrm{m}$ long). Proximal antennomeres with trichobothria on antennomeres $3-5$ in a 2, 3, 1 pattern but with long flagellum (500-800 $\mu \mathrm{m}$ long in holotype). Third antennomere with bacilliform 
sensillum ( $25 \mu \mathrm{m}$ long) in ventral position (Fig. 25). Coniform protrusion of frontal process with one anterior and four posterior micro-barbed macrosetae. Three macrosetae along each side of insertion line of antennomere and $x$ setae with micro-barbs; ratios of length in female paratype $a / i / p / x$ are $49 / 51 / 51 / 42$, respectively. Suboval labial palps large, each with bacilliform latero-external sensillum near two simple
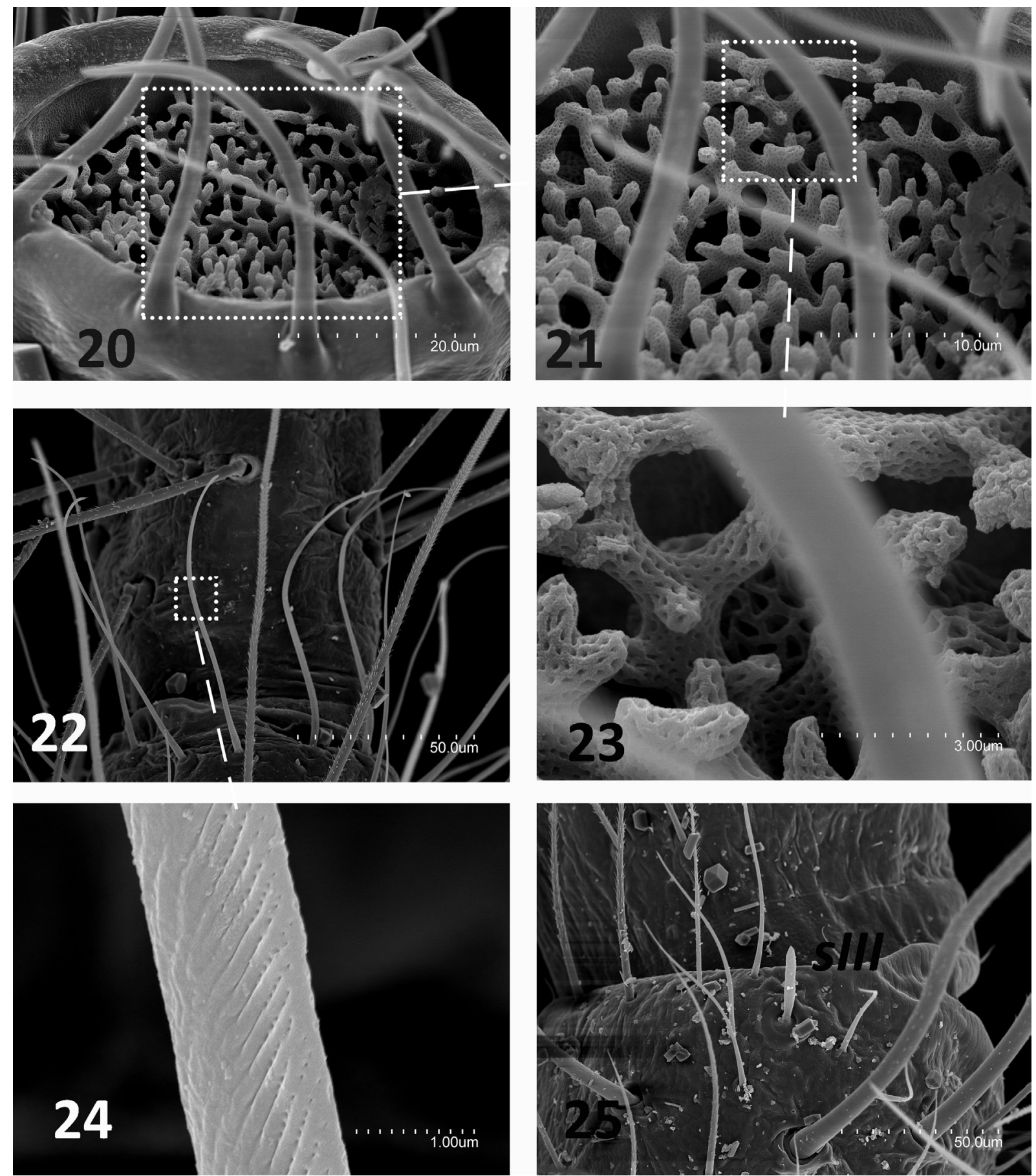

Figs 20-25. Hubeicampa melissa Sendra \& Lips gen. et sp. nov. 20. Apical view of the last antennomere. 21. Ramiform net of the olfactory chemoreceptor in the cupuliform organ. 22. Distal portion of a central antennomere. 23. Detail of the ramiform net of the olfactory chemoreceptor. 24. Detail of the gouge sensillum. 25. Ventral side of the third antennomere with its sensillum (sIII). 
setae, in posterior position with two guard setae and up to 24 setae on anterior portion, which are followed by up to 130 neuroglandular setae on posterior portion.

THORAX. Distribution of thoracic macrosetae (Figs 30-33) with pronotum with $1+1 \mathrm{ma}, 1+1 \mathrm{la} 2(1+2$ la2,3 in paratype), $2+2 l p 1,3$ macrosetae; mesonotum with $1+1 \mathrm{ma}, 1+1 \mathrm{la}$ and $1+1 \mathrm{mp}(0+0 \mathrm{mp}$ in paratype) macrosetae, and metanotum with $1+1 m a, 0+1 s m p(1+1 s m p$ in paratype) macrosetae. All macrosetae slightly thin and micro-barbed, with a few longer and thin distal barbs; marginal setae longer than clothing setae. Legs elongated and metathoracic legs overpass end of abdomen. Tibia longer than femur or tarsus (Table 3). Femora III with one short dorsal macrosetae $(0.17 \mathrm{~mm}$ in $1.88 \mathrm{~mm}$ femur of paratype-4158) (femora I-II with one dorsal macrosetae, less frequently without or with one submacrosetae instead). Calcar covered with thin abundant micro-barbs all over. Tibia I-III with one short completely micro-barbed ventral macroseta (in holotype, prothoracic legs of tibia with three and two macrosetae). Each tibia with two ventral rows of thick micro-barbed setae, scattered around tibia thin micro-barbed setiform sensilla. Three dorsal and one ventral tarsal subapical setae with micro-barbs (Figs 34, 36). Subequal elbowed claws with lateral crest; basal and ventral portions of claws covered with very small, thin, spiniform formations. Laminar lateral processes of the pretarsus completely covered with what was initially thought to be dense pubescence, but under SEM high magnifications turned out to be thick micro-barbs (Figs 34, 36-39).
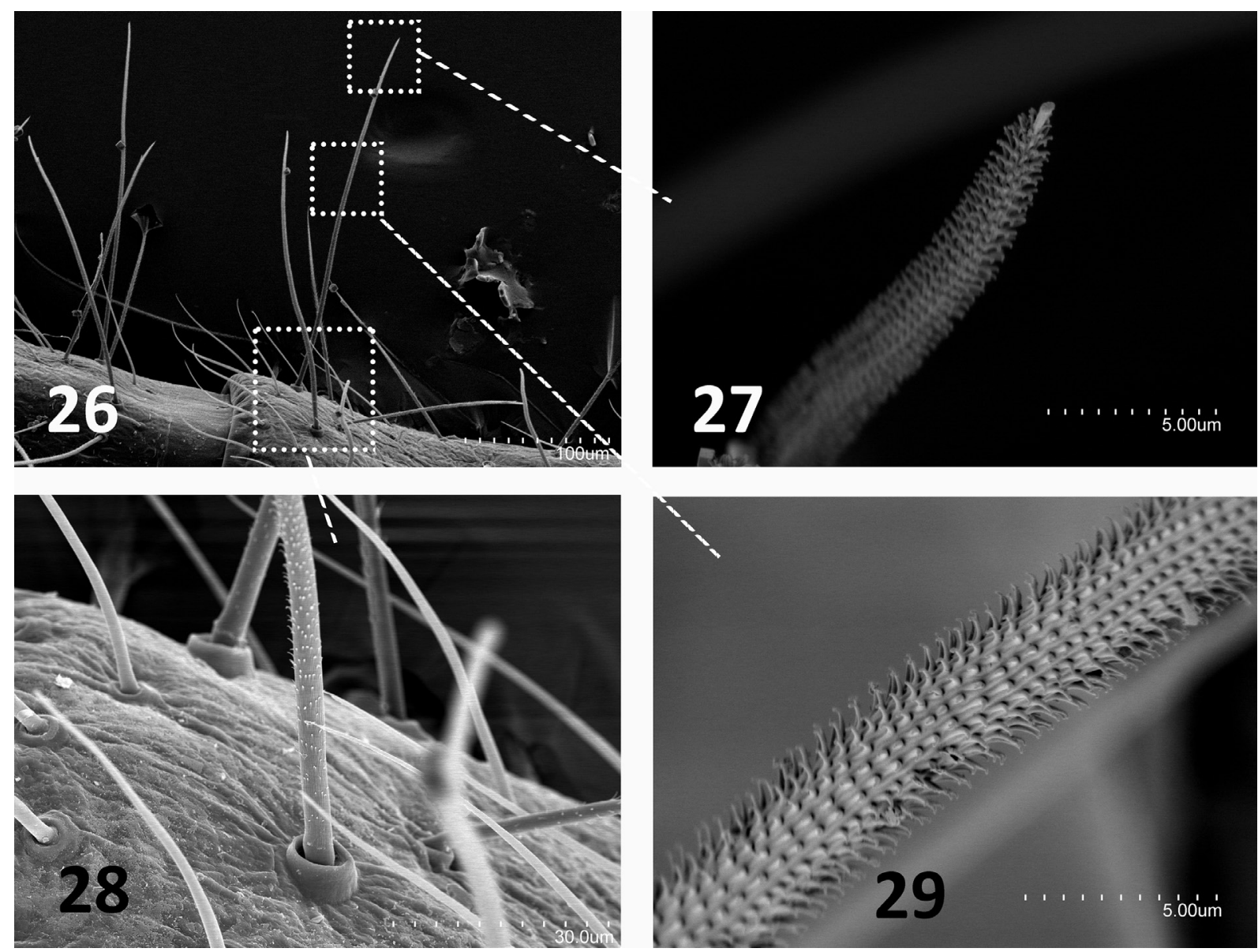

Figs 26-29. Hubeicampa melissa Sendra \& Lips gen. et sp. nov. 26. Detail of the setae and macrosetae on antennomeres. 27. Distal portion of an antenna macroseta. 28. Basal portion of an antenna macroseta. 29. Central portion of an antenna macroseta. 
Table 3. Hubeicampa melissa Sendra \& Lips gen. et sp. nov., length of the body, antennae and metathoracic leg, including their segments, and cerci (units in $\mathrm{mm}$ ) as well as number of antennomeres.

\begin{tabular}{|c|c|c|c|c|c|c|c|c|c|}
\hline \multirow[b]{2}{*}{ Specimen } & \multirow{2}{*}{$\begin{array}{l}\text { Body } \\
\text { length }\end{array}$} & \multirow{2}{*}{$\begin{array}{l}\text { Antennae } \\
\text { length }\end{array}$} & \multirow{2}{*}{$\begin{array}{c}\text { Antenno- } \\
\text { meres }\end{array}$} & \multicolumn{5}{|c|}{ Metathoracic leg } & \multirow[b]{2}{*}{ Total leg } \\
\hline & & & & coxa & trochanter & femur & tibia & tarsus & \\
\hline $\begin{array}{l}\text { Holotype-4168 } \\
\text { (MZB (MCNB) } \\
2020-1162)\end{array}$ & 9.0 & 11.2 & 49 & 0.34 & 0.25 & 1.58 & 1.98 & 1.64 & 5.79 \\
\hline $\begin{array}{l}\text { Paratype-4158 } \\
\text { (MZB (MCNB) } \\
\text { 2020-1165) }\end{array}$ & 10.8 & - & - & 0.50 & 0.46 & 1.88 & 2.51 & 1.95 & 7.30 \\
\hline
\end{tabular}

AвDOMEN. Distribution of abdominal macrosetae on tergites (Fig. 40): $1+1$ post 1 on $\mathrm{V}$ tergite, $(1$ post 1 +2 post 1,5 on paratype); $3+3$ post $2,4,5$ on VI tergite, $3+3$ post $1,4,5$ ( $3+2$ post 4,5 in holotype) on VII tergite, 4 post $1,3,4,5+5$ post $1-5$ ( $5+5$ (post $1-5$ in paratype) on VIII tergite; and $6+6$ post on IX abdominal segment. Short micro-barbed abdominal macrosetae with few distal barbs on urotergites $\mathrm{V}-$ VII; urotergite VIII and abdominal segment with similar but longer macrosetae. Urosternite I with $12+12$ macrosetae (Fig. 41); urosternites II to VII with 5+5 macrosetae; urosternite VIII with 1+1 macrosetae; urosternal macrosetae complete covered by micro-barbs including a few distal short barbs. Stylus with apical, subapical and ventromedial setae completely covered with both micro-barbs and one apical barb (Figs 42-43). Cerci $1.7 \times$ as long as body length in two presumably regenerated cerci of paratype, with six primary articles (Table 4). Length of cerci quickly increases from proximal to distal articles, covered with long setae, and macrosetae covered with micro-barbs; each primary article with single apical whorl of shorter and thinner setae also covered with micro-barbs (Figs 44-45).

SeCondary SeX Characters. Female urosternite I with coniform appendages, each bearing up to 12 glandular $a 1$ setae in apical field (Fig. 41). Male urosternite I with subcylindrical enlarged appendages with large field of glandular $a 1$ sertae; without glandular $g 1$ setae.

Hubeicampa aff. melissa Sendra \& Lips gen. et sp. nov.

\section{Material examined}

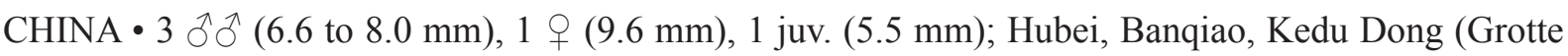
des Têtards); 6 Aug. 2009; Josiane Lips leg.; Coll. AS.

\section{Remark}

Specimens from Kedu Dong are considered as $H$. aff. melissa gen. et sp. nov. due to the specimens' bad condition which does not allow us to clearly observe any variations in the taxonomical features. Nevertheless, they have the same important traits as the new species, but there is no dorsal macrosetae on the femur, except in a juvenile.

\section{Taxonomic affinities}

Hubeicampa melissa Sendra \& Lips gen. et sp. nov. is closely related to another cave-adapted species, Hubeicampa lipsae (Condé, 1993), which is a new combination of Plusiocampa (Dydimocampa) lipsae Condé, 1993, and thus leads us to propose Hubeicampa as a new genus for both species that live in karst regions of the Chinese province of Hubei. The new genus is distinguished by the pretarsus, which has lateral crests and a laminar lateral process covered by spiniform formations and micro-barbs, pubescent setae and macrosetae (Figs 36-39), as well as by 1+1 macrosetae on the eighth urosternite. 


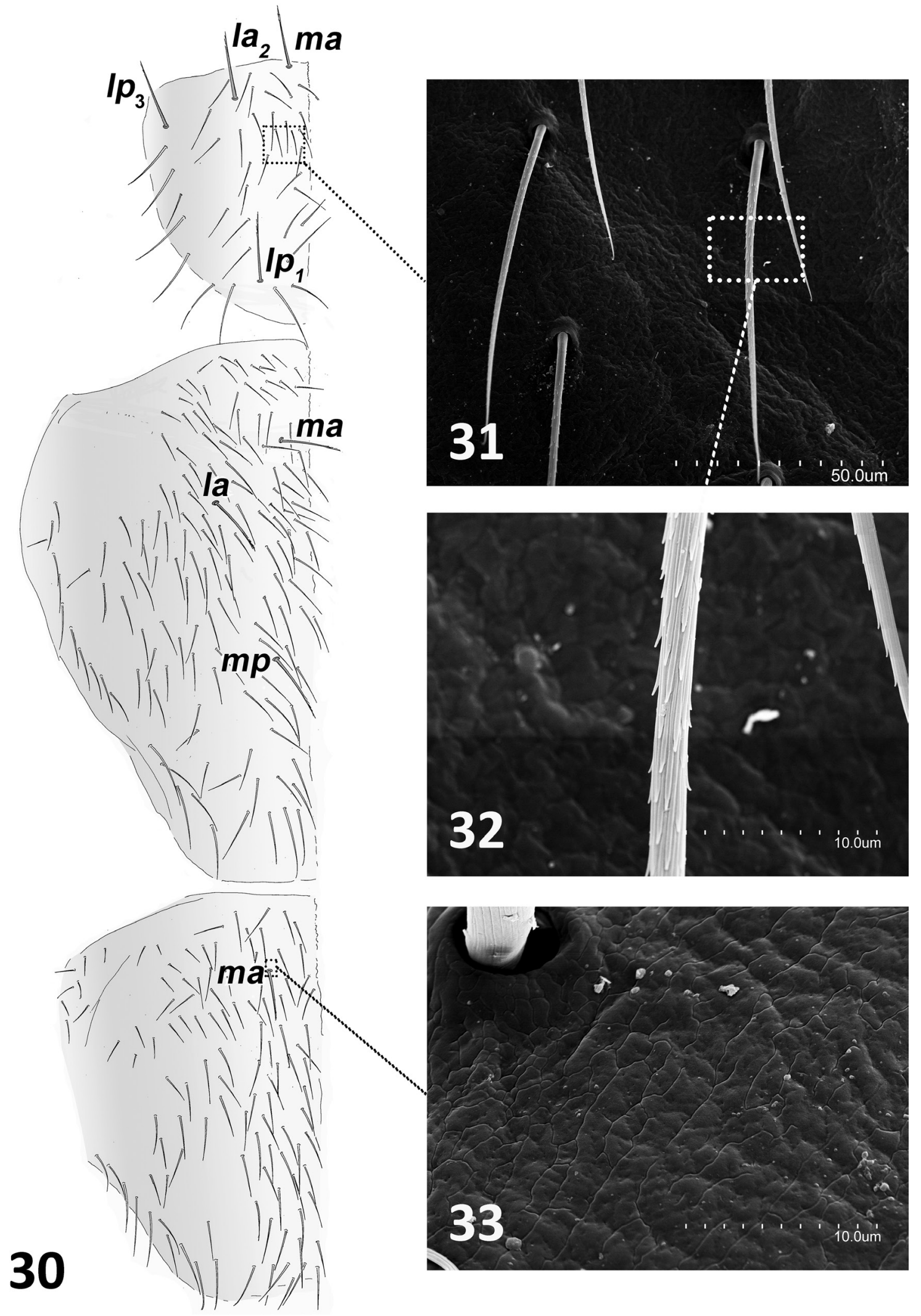

Figs 30-33. Hubeicampa melissa Sendra \& Lips gen. et sp. nov. 30. Pronotum, mesonotum, and metanotum, left side, holotype (MZB (MCNB) 2020-1162). 31. Detail of the pronotum. 32. Detail of clothing setae on pronotum. 33. Detail of the surface of metanotum. 
A significant number of taxonomic characters separates $H$. melissa gen. et sp. nov. from H. lipsae. The most relevant differences are in the number of macrosetae on the mesonotum (Fig. 30) (with 1+1 medial anterior, $1+1$ lateral anterior and $1+1$ medial posterior macrosetae in $H$. melissa gen. et sp. nov. instead of $1+1$ medial anterior and 2+2 lateral posterior macrosetae in $H$. lipsae), and the number of macrosetae on metanotum (with $1+1$ medial anterior macrosetae and none or $1+1$ medial posterior submacrosetae
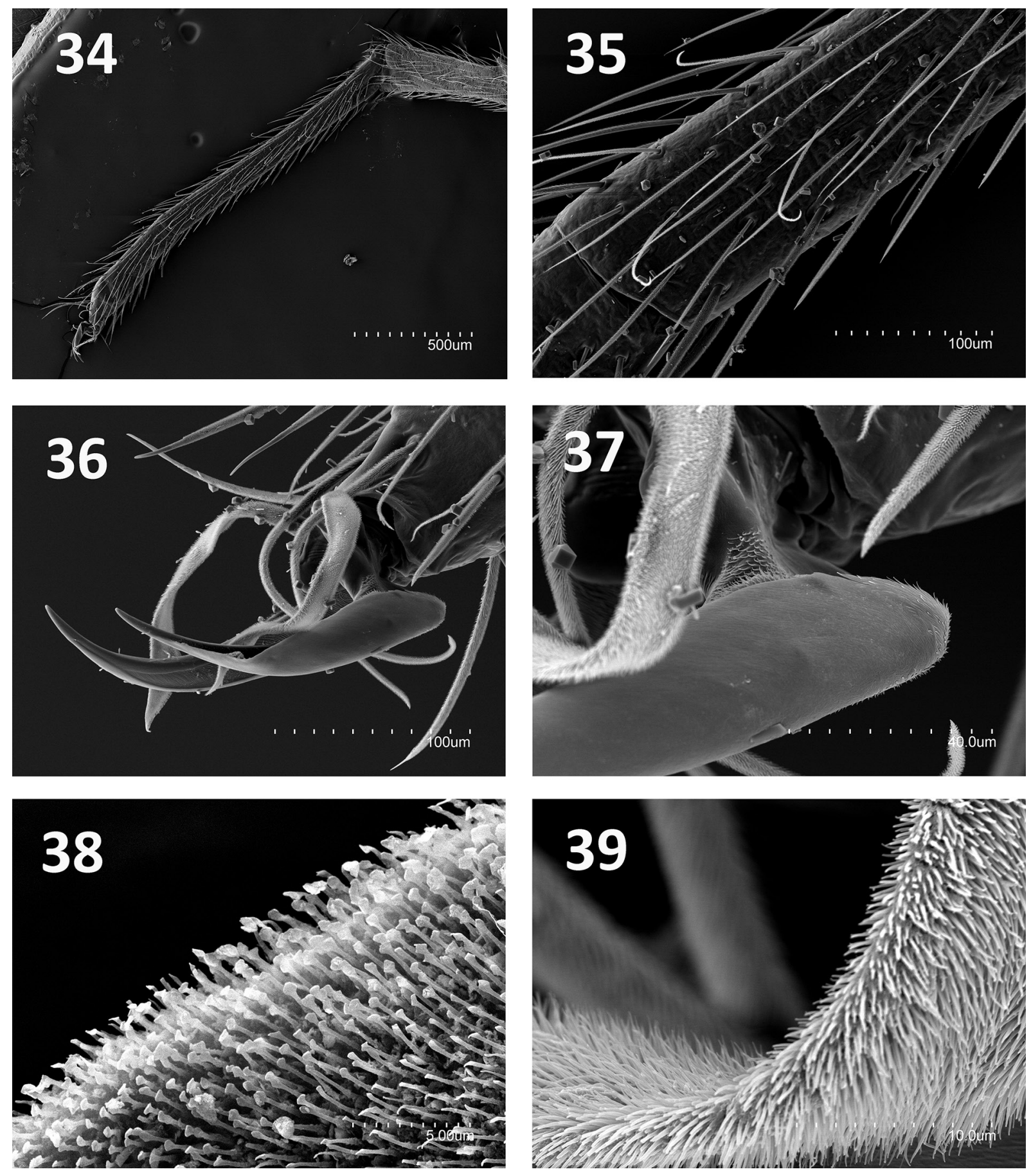

Figs 34-39. Hubeicampa melissa Sendra \& Lips gen. et sp. nov. 34. Tarsus of metathoracic leg. 35. Medial portion of tarsus. 36. Pretarsus. 37. Detail of the posterior portion of a claw. 38. Detail of the distal part of a lateral process. 39. Detail of the lateral part of a lateral process. 

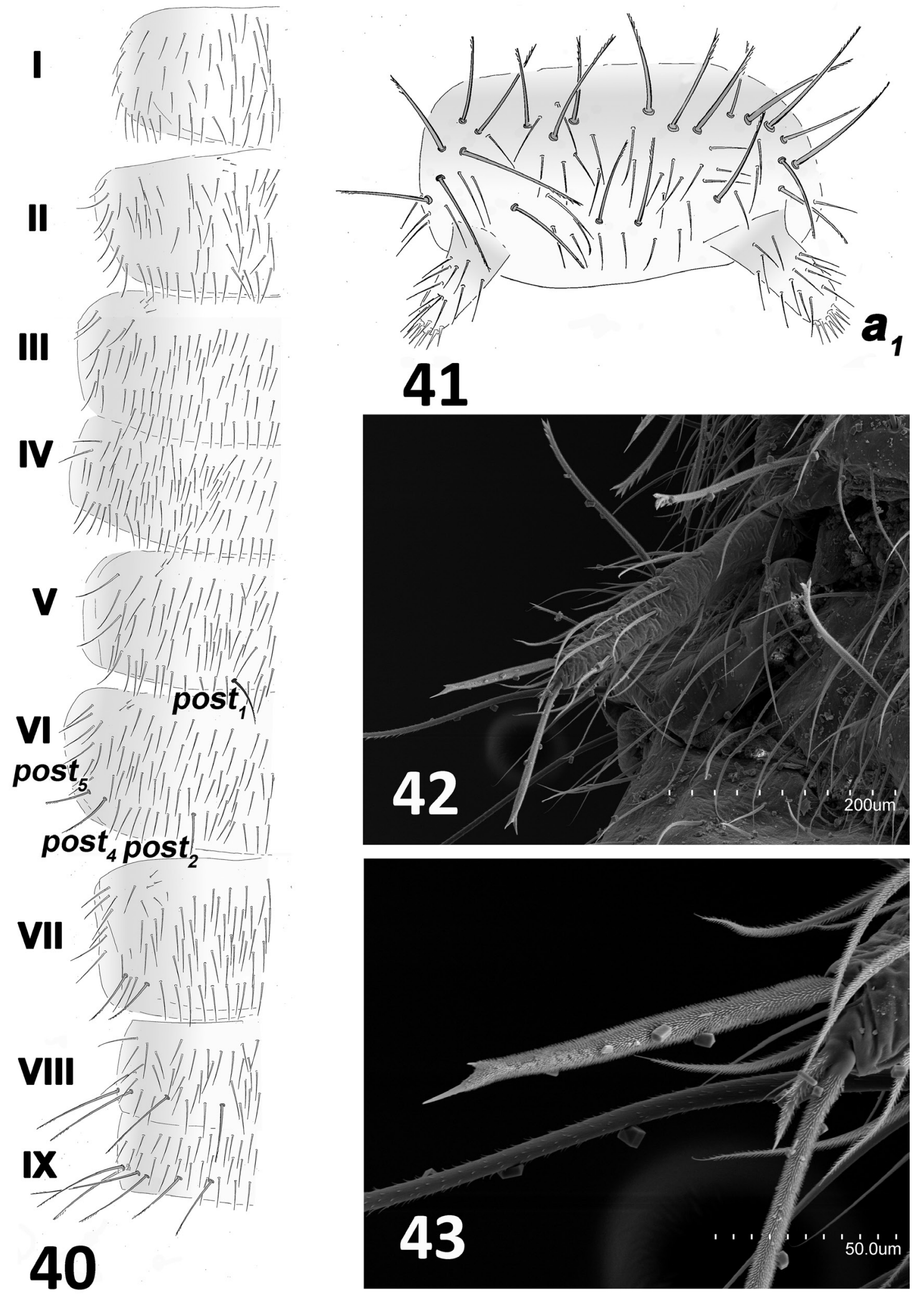

Figs 40-43. Hubeicampa melissa Sendra \& Lips gen. et sp. nov. 40. Urotergites I-VII and abdominal segment IX, left side, holotype (MZB (MCNB) 2020-1162). 41. First urosternite of a female, holotype (MZB (MCNB) 2020-1162, with glandular $a_{1}$ setae. 42. Stylus, right fifth urosternite. 43. Detail stylus, right fifth urosternite. 
Table 4. Hubeicampa melissa Sendra \& Lips gen. et sp. nov. (paratype MZB (MCNB) 2020-1165), cercal articles length and total length (units in $\mathrm{mm}$ ), including number of articles of the cerci, basal article included, and division of basal article in secondary articles.

\begin{tabular}{ccccccccccc}
\hline $\begin{array}{c}\text { Divisions of the } \\
\text { basal article }\end{array}$ & Basal article & $\mathbf{1}^{\text {st }}$ & $\mathbf{2}^{\text {nd }}$ & $\mathbf{3}^{\text {rd }}$ & $\mathbf{4}^{\text {th }}$ & $\mathbf{5}^{\text {th }}$ & $\mathbf{6}^{\text {th }}$ & Total cercus & Number of articles \\
\hline 3 & 2.30 & 1.25 & 1.90 & 2.35 & 2.87 & 3.26 & 3.85 & 17.78 & 7 \\
\hline 3 & 2.60 & 1.30 & 1.89 & 2.31 & 2.86 & 3.24 & 3.95 & 18.15 & 7 \\
\hline
\end{tabular}

instead of $1+1$ medial anterior and $1+1$ lateral posterior in $H$. lipsae). Other important features are the larger lateral crests in the pretarsus of H. melissa gen. et sp. nov. (Figs 36-37) the presence of one dorsal macroseta on the metathoracic femora, and one ventral macroseta on the metathoracic tibia in H. melissa gen. et sp. nov. instead of two dorsal femora and two ventral tibia macrosetae in H. lipsae. Finally, there are $4+4$ posterior macrosetae on V-VII urotergites in H. melissa gen. et sp. nov. (Fig. 40) instead of 3+3 in H. lipsae.

\section{Remarks}

Hubeicampa melissa Sendra \& Lips gen. et sp. nov. lives in the "Grotte du $8^{\text {ième }}$ Ciel Baxian Dong”, a cave situated at an elevation of $1870 \mathrm{~m}$ in the mountain near Banqiao village in the Hubei Province. The cave is $1703 \mathrm{~m}$ long and $122 \mathrm{~m}$ deep, with a huge entrance and giant galleries, as well as narrow passages and a narrow independent entry. The holotype of Hubeicampa melissa gen. et sp. nov. was observed and collected on the cave floor at about $300 \mathrm{~m}$ from the huge entry and at the top of the -40 $\mathrm{m}$ deep pit on clay ground above the Saltpetre passage (Lips et al. 2009) (Figs 46-48). Some paratypes were collected in the same cave in the big chamber "Grande galerie du Va-et-Vient".
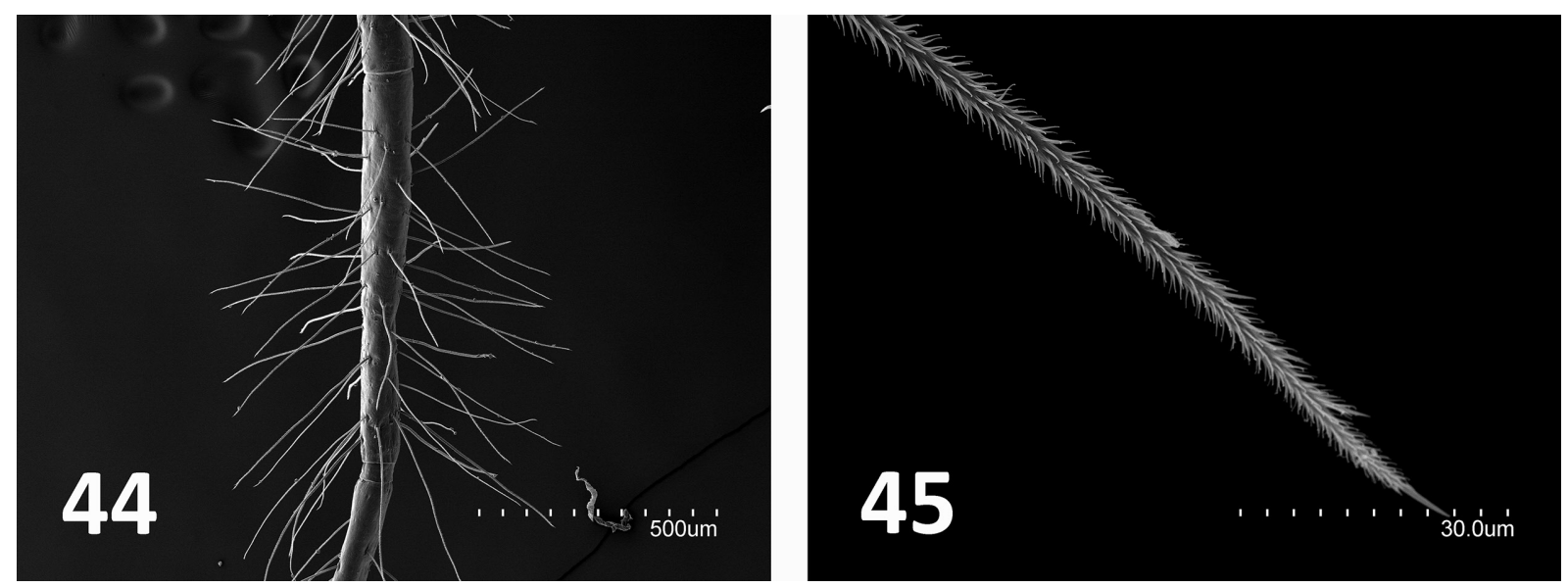

Figs 44-45. Hubeicampa melissa Sendra \& Lips gen. et sp. nov. 44. Central cercal articles. 45. Detail of a cercal macroseta. 


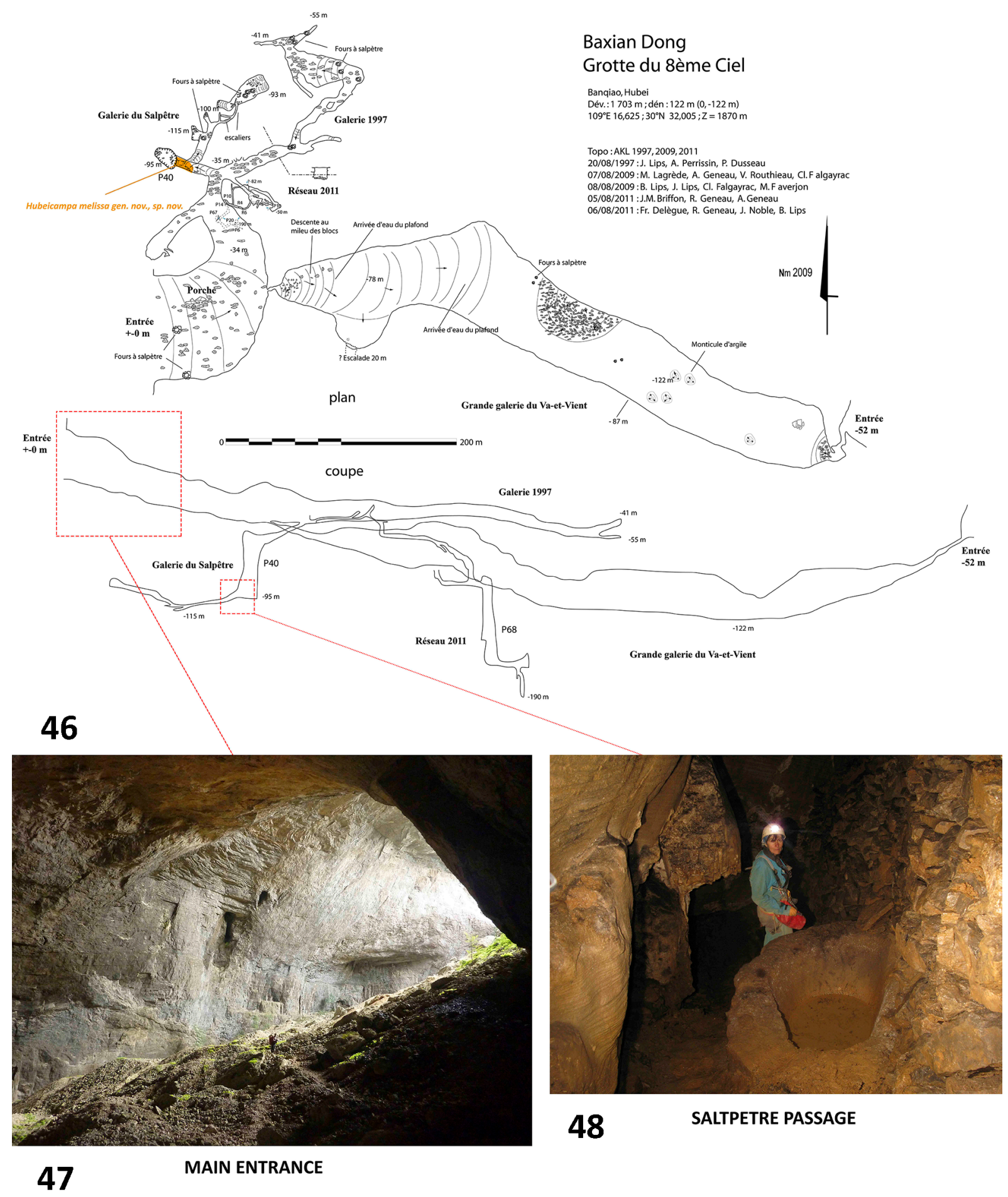

Figs 46-48. Grotte du $8^{\text {ième }}$ Ciel Baxian Dong, Banqiao, Hubei, China. 46. Map of the cave. 47. Main entrance. 48. Saltpetre passage with an old saltpetre oven. (Photographs Josiane Lips). 
Genus Plutocampa Chevrizov, 1978

Diagnosis (modified and improved from the original diagnosis by Chevrizov 1978)

Thick sensilla on third antennomere and labial palps. Thoracic macrosetae with no less than $5+5$ macrosetae on pronotum, $5+5$ on mesonotum $(1+1$ medial posterior included), and $4+4$ on metanotum (1+1 medial posterior included). Two dorsal macrosetae on metathoracic femora and one on tibia. Unequal elbowed claws with lateral crests without lateral processes. Urotergites V-VII with $4+4$ posterior macrosetae and without lateral anterior macrosetae. Up to $6+6$ macrosetae on first urosternite, $4+4$ macrosetae on second to seventh urosternites, and 1+1 macrosetae on eighth urosternite.

\section{Plutocampa speophila Chevrizov, 1978}

Plutocampa speophila Chevrizov, 1978: 201, fig. 2(1-9).

\section{Material examined}

RUSSIA $\odot$, holotype $(6 \mathrm{~mm}), 1$ p paratype $(5 \mathrm{~mm})$; Far East, Primorye region, Olgisk District, Priiskovaya cave; 3 Nov. 1966; S.I. Ljovuschkin leg.; slide; ZMMU Dip0007.

\section{Redescription (based on Chevrizov 1978)}

Under optical microscope it has a smooth cuticle covered by thin smooth clothing setae. Antennae are apparently intact with 23 antennomeres in the paratype, medial antennomeres $1.4 \times$ as long as wide; third antennomere with a thick sensillum in ventral position ( $c-d$ macrosetae); last antennomere with at least eight olfactory chemoreceptors. Small and pointed frontal process has one long anterior smooth macrosetae and two shorter posterior macrosetae; there are three smooth macrosetae along each side of the line of insertion of antennomere and smooth $x$ setae with a similar length, ratios of $a / i / p / x$ are $20 / 23 / 22 / 23$, respectively. Labial palps are large with thick sensilla. Pronotum with $1+1 m a, 3+3(2+2$ paratype) $l a, 2+2 l p_{l, 3}$ mesonotum with $1+1 m a, 3+3$ (2+2 paratype) la, $2+2 l p_{2,3}, 1+1(0+1$ paratype) $m p$ and metanotum with $1+1 m a, 2+2 l p, 1+1 m p$ macrosetae, long and thin notal macrosetae covered with thin barbs along their distal three-fourths; marginal setae are long and some of them are as long and barbed as the macrosetae. The metathoracic legs reach the posterior border of the VII abdominal segment; femora have two long barbed dorsal macrosetae and one ventral macrosetae. The tibia has one ventral short macrosetae, a few distal barbs, and calcars with several long barbs. The tarsus has two rows of smooth ventral setae, slightly thicker than clothing setae and on distal part: three long smooth dorsal setae and one ventral seta; the pretarsus has no lateral processes, with unequal elbowed claws, and with large lateral crests. Urotergite I with 1+1 post $_{1}$; urotergite II 1+2 (1+1 paratype) post ${ }_{1,2}$; urotergite III $2+2$ post $_{l, 2}$; urotergites IV-VII 4+4 post $_{l-4}$; urotergite VIII $5+5$ post $_{l-5}$ and abdominal segment IX 7+7 post, macrosetae long with barbs along three-fourths. Urosternite I with 5+5, urosternites II-VII $4+4$, and urosternite VIII 1+1 macrosetae; urosternal macrosetae are shorter than urotergal macrosetae with long barbs; smooth stylar setae. First urosternite appendages (female) have large, short and subconical appendages, each with apical field with about fifty glandular $a_{1}$ setae.

\section{Plutocampa methoria Chevrizov, 1978}

Figs 49-50

Plutocampa methoria Chevrizov, 1978: 202, fig. 3(1-10).

\section{Material examined}

RUSSIA • + , holotype (5.6 mm); Far East, Primorye region, environs of Khasan Lake; 17 May 1973; S.I. Ljovuschkin leg.; slide; ZMMU Dip0002. 
CHINA 1 1 + $(5.4 \mathrm{~mm}), 1$ $(3.9 \mathrm{~mm})$; Liaoning Province, Benxi, Haunren, Pylone Cave 4; 17 May 2019; Deharveng and Bedos leg.; sample code CHILN19-007; NEIGAE.

\section{Redescription (based on Chevrizov 1978)}

Under optical microscope, one can see a smooth cuticle covered by thin and smooth clothing setae. The more complete antennae is apparently regenerated and it has 23 antennomeres in the $5.4 \mathrm{~mm}$ adult from Grotte du Pylone; the third antennomere has a thick sensillum in ventral position ( $d-e$ macrosetae) (Fig. 49). The small and pointed frontal process has one long and smooth anterior macroseta and two shorter posterior macrosetae; there are three smooth macrosetae along each side of the insertion line of the antennomere and smooth $x$ setae with similar length, ratios of $a / i / p / x$ are 14/19/14/19 in the holotype, respectively. The labial palps have a large thick sensilla (Fig. 50). Pronotum with $1+1 \mathrm{ma}$, $2+2 l a, 2+2 l p_{l, 3}$, mesonotum with $1+1 \mathrm{ma}, 2+2(2+1) l a, 2+2 l p_{2,3}, 1+1 \mathrm{mp}$, and metanotum with $1+1$ $m a, 0-1+1 l a, 2+2 l p_{2,3}, 1+1 m p$ macrosetae; long and thin notal macrosetae with thin barbs along their distal three-fourths; marginal setae are long and barbed as the macrosetae. Metathoracic legs reach the posterior border of the V-VI abdominal segment; femora has two long, barbed dorsal macrosetae and one ventral macroseta, while the tibia has one short ventral macroseta, a few distal barbs, and calcars with several long barbs; the tarsus has two rows of smooth ventral setae slightly thicker than the clothing setae, and in the distal portion: three long, smooth dorsal setae, one ventral seta and one distal seta; the pretarsus is without lateral processes, with unequal elbowed claws and large lateral crests. Urotergite I-II with 1+1 post $t_{1}$; urotergite III with $2+2$ post $_{1,2}$; urotergites IV-VII with 4+4 post l- $_{\text {; }}$ urotegite VIII with $5+5$ post $_{1-5}$ and abdominal segment IX $7+7$ with post, macrosetae are long with barbs along their distal three-fourths. Urosternite I with $6+6$, urosternites II-VII with $4+4$ and urosternite VIII with $1+1$ macrosetae; urosternal macrosetae shorter than urotergal macrosetae with long barbs; smooth stylar setae. Appendages of the first urosternite (female) with large, short and subcylindrical appendages, each with apical field of glandular $a_{1}$ setae. The most complete cercus is regenerated and it has six primary articles and a basal article, which are covered by several whorls of barbed macrosetae with long barbs along the third distal and a few whorls of smooth setae.

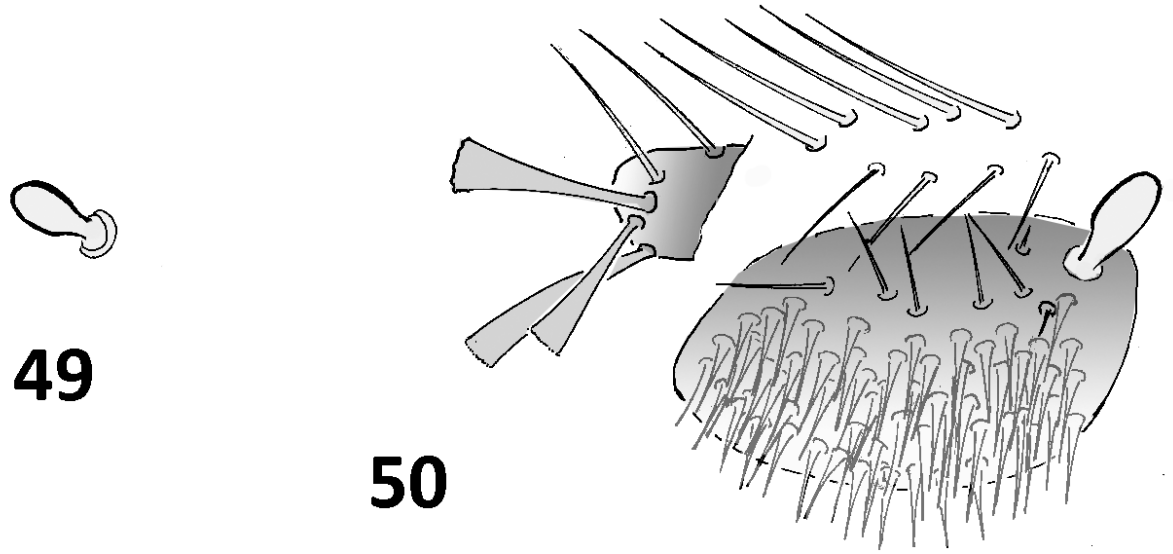

Figs 49-50. Plutocampa methoria Chevrizov, 1978. 49. Sensillum of the third antennomere. 50. Left labial palp and palpiform process (pp). 
Plutocampa paurochaeta Chevrizov, 1978

Plutocampa paurochaeta Chevrizov, 1978: 204, fig. 3(11-19).

\section{Material examined}

RUSSIA $\bullet+$ holotype $(6.7 \mathrm{~mm})$; Far East, Primoriye region, Chandolaz Mt. Range, Solyanik Cave; 25 Jun. 1974; P.B. Chevrizov leg.; slide; ZMMU Dip0005.

\section{Redescription (based on Chevrizov 1978)}

Under optical microscope, one can see a smooth cuticle covered by thin smooth clothing setae. Antennae, apparently intact, have 28 antennomeres, the central antennomere is $1.6 \times$ as long as wide, the apical antennomere has about eight olfactory chemoreceptors; the third antennomere has a large sensillum in ventral position. The head has a small and pointed frontal process with one long anterior smooth macroseta and two shorter posterior macrosetae; three smooth macrosetae along each side of the insertion line of the antennomere and smooth $x$ setae with similar length, ratios of $a / i / p / x$ are $6 / 5 / 8 / 7$, respectively. Pronotum with $1+1 m a, 2+2 l a, 2+2 l p_{l, 3}$, mesonotum with $1+1 m a, 2+1 l a, 2+2 l p_{2,3}$, and metanotum with $1+1 \mathrm{ma}, 2+2 \mathrm{lp}$ macrosetae, notal macrosetae are long and thin with thin barbs on three-fourths of distal barbs; marginal setae are long and smooth. Metathoracic legs overpass the end of the abdomen; femora have two long barbed dorsal macrosetae and one ventral macroseta, and the tibia has one ventral short macroseta and calcars with several long barbs. The tarsus has two rows of ventral smooth setae slightly thicker than the clothing setae, three long and smooth dorsal subapical setae and one ventral subapical seta; the pretarsus is without lateral processes, with unequal elbowed claws, and with large lateral crests. Urotergite IV with $1+1$ post $_{l}$, urotergites V-VII with $4+4$ post $_{1-4}$, urotegite VIII with $5+5$ post $_{I-5}$, macrosetae are long, with barbs along their three-fourths. Urosternite I with $6+6$, urosternites II-VII with $4+4$, and urosternite VIII with 1+1 macrosetae; urosternal macrosetae are shorter than urotergal macrosetae with long barbs; smooth stylar setae. First urosternite appendages (female) have large, short subconical glandular $a_{1}$ setae with a smaller apical field. The cerci have eight articles plus a basal one covered with whorls of smooth setae and whorls of macrosetae barbed with thin barbs at the proximal articles to smooth in medial and distal articles.

Subfamily Campodeinae Condé, 1956

Genus Pacificampa Chevrizov, 1978

\section{Diagnosis (based on Chevrizov 1978)}

Thoracic macrosetae with no more than $3+3$ macrosetae on pronotum, $4+4$ on mesonotum $(2+2$ lateral posterior included), and $2+2$ on metanotum (1+1 lateral posterior included). One dorsal macroseta on metathoracic femora and one or two on tibia. Subequal elbowed claws with ridges on dorsal side that look like very small lateral crests under optical microscope; without lateral processes. Urotergites $\mathrm{V}-$ VII with no more than $1+1$ medial posterior, $1+1$ lateral anterior and $2+2$ lateral posterior macrosetae and on urotergite VIII with no more than $1+1$ medial posterior and $3+3$ lateral macrosetae. Up to $7+7$ macrosetae on first urosternite, $5+5$ macrosetae on second to seventh urosternites, and 1+1 macrosetae on eighth urosternite. First urosternite in males with thick appendages with large field of glandular a1 setae.

\section{Pacificampa birsteini Chevrizov, 1978}

Pacificampa birsteini Chevrizov, 1978: 198, fig. 1(1-9).

\section{Material examined}

RUSSIA $\bullet q$ holotype (7 mm); Far East, Primoriye region, Partizanskii Mountain Range, Belyi Dvorets Cave (White Palace Cave); 16 Aug. 1966; S.I. Ljovushkin leg.; slide; ZMMU Dip0003. 


\section{Redescription (based on Chevrizov 1978)}

It has a smooth cuticle, under optical microscope, covered by abundant short smooth clothing setae. The antennae are apparently intact with 26 antennomeres; the medial antennomeres are $3 \times$ as long as wide, and the last antennomere has about eight spheroidal olfactory chemoreceptors; the third antennomere has a sensillum in ventral position ( $c-d$ macrosetae). The plain frontal process has one long anterior smooth macrosetae and two, almost two times shorter, posterior macrosetae; the three macrosetae have a few thin distal barbs along each side of the insertion line of antennomere longer than the smooth $x$ setae, with length ratios of $a / i / p / x, 5 / 6 / 5 / 2$, respectively. Pronotum with $1+1 m a, 1+1 l a, 1+1 l p$, mesonotum with $1+1 m a, 1+1 l a, 2+2 l p$, and metanotum with $1+1 m a, 1+1 l p$ macrosetae; all notal macrosetae are robust with a few short distal barbs; the marginal setae are thicker than the clothing setae with short distal barbs, whereas the lateral posterior marginal setae are larger with abundant small barbs. The metathoracic legs overpass the end of the abdomen; the femora have one dorsal robust macroseta with 2-3 distal barbs, the tibia has two short ventral macrosetae with 1-2 apical barbs and the calcars have 3-4 long barbs; the tarsus has two rows of smooth robust ventral setae, three long smooth dorsal and one distal ventral setae; the pretarsus is without lateral processes, with subequal elbowed claws and with a smooth ventral surface, ridged on the dorsal side, that looks like very small lateral crests under optical microscope, but they are not. Urotergite IV with $1+0 l a, 0-1 l p$; urotergites V-VII with $1+1 m a, 1+1 l a$, $2+2 l p$; urotergite VIII and abdominal segment IX with $1+1 m p, 3+3 l p$, all macrosetae are robust with a few short distal barbs. Urosternite I with $6+6$, urosternites II-VII with $5+5$, and urosternite VIII with 1+1 macrosetae; all urosternal macrosetae are robust with a few long barbs; robust smooth stylar setae. First urosternite appendages (female) are subcylindrical and long with an apical field of $a_{l}$ glandular setae. Cercal articles have whorls of long macrosetae with a few distal barbs.

\section{Pacificampa caesa Chevrizov, 1978}

Pacificampa caesa Chevrizov, 1978: 199, figs 1(10-19).

\section{Material examined}

RUSSIA $-\widehat{o}$ holotype $(6.8 \mathrm{~mm})$; Far East, Primoriye region, Chandolaz Mountain Range, Bliznets Cave; 23 Jun. 1974; B.P. Chevrizov leg.; slide; ZMMU Dip0004.

\section{Redescription (based on Chevrizov 1978)}

It has a smooth cuticle under optical microscope and is covered by abundant short and smooth clothing setae. The antennae are apparently intact with 27 antennomeres, medial antennomeres are $3 \times$ as long as wide; third antennomere has a sensillum in ventral position ( $c-d$ macrosetae). The plain frontal process has one long anterior smooth macroseta and two, almost two times shorter, posterior macrosetae; the three macrosetae with short distal barbs along each side of the insertion line of the antennomere are longer than the smooth $x$ setae with length ratios of $a / i / p / x, 7 / 8 / 4 / 3$, respectively. Pronotum with $1+1 m a$, $1+1 l a, 1+1 l p$, mesonotum with $1+1 m a, 1+1 l a, 2+2 l p$, and metanotum with $1+1 m a, 1+1 l p$ macrosetae; all notal macrosetae are robust with a few short distal barbs, in particular the $l a$ are longer and the $l p$ pronotal macrosetae have more numerous short distal barbs; the marginal setae are thicker than the clothing setae with short distal barbs, the lateral posterior marginal setae are larger and have more numerous small barbs. The metathoracic legs reach the end of the abdomen; the femora have one robust dorsal macroseta with short distal barbs, whereas the tibia has one ventral short macroseta with 1-2 apical barbs and the calcars are with 3-4 long barbs; the tarsus has two rows of robust, smooth ventral setae, three long, smooth dorsal and one distal ventral setae; the pretarsus is without lateral processes, with subequal elbowed claws, and with a smooth ventral surface ridged on the dorsal side that looks like very small lateral crests under optical microscopes, but they are not. Urotergites V-VII have $1+1 \mathrm{ma}$, $1+1 l a, 2+2 l p$; urotergite VIII and abdominal segment IX has $1+1 \mathrm{mp}, 3+3 l p$, all macrosetae are robust 
and with a few short distal barbs. Urosternite I has $6+6$, urosternites II-VII $5+5$, and urosternite VIII $1+1$ macrosetae; all urosternal macrosetae are robust and with a few long barbs; robust smooth stylar setae. First urosternite appendages have (male) subcylindrical appendages thick, each of these has a large apical field with more than one hundred glandular $a_{1}$ setae.

Pacificampa wudonghuii Sendra sp. nov.

urn:lsid:zoobank.org:act:447EE93A-F466-4C66-827A-0751A259070F

Figs 51-64

\section{Etymology}

This species is dedicated to Professor Wu Donghui, from the Northeast Institute of Geography and Agroecology (NEIGAE), Chinese Academy of Sciences, Changchun (China), for his enthusiastic contribution and support to the knowledge of Northern China soil and cave biodiversity.

\section{Type material}

\section{Holotype}

CHINA • P; Liaoning Province, Benxi, Huanren, Xianren Dong; 17 May 2019, L. Deharveng, A. Bedos and Wu Donghui leg.; labelled "CHILN19-005-holotype"; NEIGA-diplura-01.

\section{Paratypes}

CHINA 1 1 + 1 juvenile, same collection data as for holotype; labelled "CHILN19-005-female paratype"; MZB (MCNB) 2020-1160 • 1 juvenile; same collection data as for preceding; labelled "CHILN19005-juvenile paratype"; MZB (MCNB) 2020-1161 • 1 क; Liaoning Province, Benxi, Huanren, Pylon cave; 17 May 2019; L. Deharveng, A. Bedos and Wu Donghui leg.; labelled "CHILN19-007-female paratype"; MZB (MCNB) 2020-1164.

\section{Other material examined}

CHINA $\bullet 1 \hat{\jmath}$, same collection data as for holotype; mounted on an aluminium stage and coated with palladium-gold; Coll. AS.

\section{Description}

Body. Length $6.5-6.9 \mathrm{~mm}$ in females; $3.9 \mathrm{~mm}$ in one juvenile. Epicuticle smooth under optical microscope but well reticulated under high magnifications as one can see irregular polygonal structures of variable sizes with scattered external glands either visible or covered with secretion (Figs 51, 53); body with smooth clothing setae.

HEAD. Antennae broken in all specimens; central antennomeres with two whorls of distal barbed macrosetae and uneven short setae; in addition, with single distal whorl of up to 8-12 gouge sensilla of 22-29 $\mu \mathrm{m}$ long (Fig. 51) and among them one or two small coniform sensilla (5 $\mu \mathrm{m}$ long). Proximal antennomeres with typical trichobothria disposition with bacilliform sensillum (9-10 $\mu \mathrm{m}$ long) on third antennomere in ventral position, between $c-d$ macrosetae (Fig. 52). Plain frontal process with one anterior macrosetae, longer than clothing setae. Three macrosetae along each side of insertion line of antennomere and $x$ setae with length ratios of $a / i / p / x, 42 / 55 / 42 / 45$, respectively, in holotype (Fig. 54). Large suboval labial palps, each with enlarged coniform latero-external sensillum near two gard setae and eight normal setae on anterior portion, up to 150 neuroglandular setae in medial and posterior positions.

THORAX. Thoracic macrosetae distribution: pronotum has $1+1 \mathrm{ma}, 1+1 \mathrm{la}, 1+1$ lp macrosetae; mesonotum has $1+1 m a, 1+1 l a$ and $2+2 l p$ macrosetae; and metanotum has $1+1 m a$ and $1+1 l p$ macrosetae. Long macrosetae with long barbs in distal three-fourths; marginal setae longer than clothing setae, which are 
barbed from distal half to three-fourths. Legs elongated, metathoracic legs reach posterior border of seventh abdominal segment. Mesothoracic and metathoracic femora have one dorsal macroseta each, barbed along distal three-fourths (Fig. 55), absent in prothoracic femora. Calcars with two or three long barbs in middle (Fig. 56). Prothoracic and mesothoracic tibia with one short ventral macrosetae with one apical barb and two in metathoracic tibia (Fig. 57). Each tarsus with two separated ventral rows of thicker and longer setae among clothing setae, and a few setiform sensilla (Fig. 58). Three long smooth dorsal tarsal and one ventral setae. Subequal elbowed claws with smooth ventral surface ridged on dorsal side that can be mistaken for lateral crests under optical microscopes, between a blunt unguiculus and without lateral processes (Figs 59-60).

ABDomen. Distribution of abdominal macrosetae on tergites (Fig. 61 shows $1+1 m a$ on III in the paratype from Grotte du Pylone, but absent in Xianren Dong Cave types; $1+1 m a, 1+1 l a$ and 2+2 lp on IV-VII; $1+1 \mathrm{mp}$ and $3+3 l p$ on VIII and $1+1 \mathrm{mp}$ and $5+5 \mathrm{lp}$ on IX abdominal; $m a$ and $l a$ macrosetae with barbs in distal half to one third and shorter than $m p$ and $l p$ macrosetae, which bear long barbs along distal four-fifths. Urosternite I with $7+7$ macrosetae (Fig. 62); urosternites II to VII with 4+4 macrosetae (Fig. 63); urosternite VIII with 1+1 macrosetae (Fig. 64); urosternal macrosetae of varying lengths, with one apical to twenty distal long barbs. Stylus setae smooth, apical and subapical setae shorter than ventromedial seta (Fig. 63).
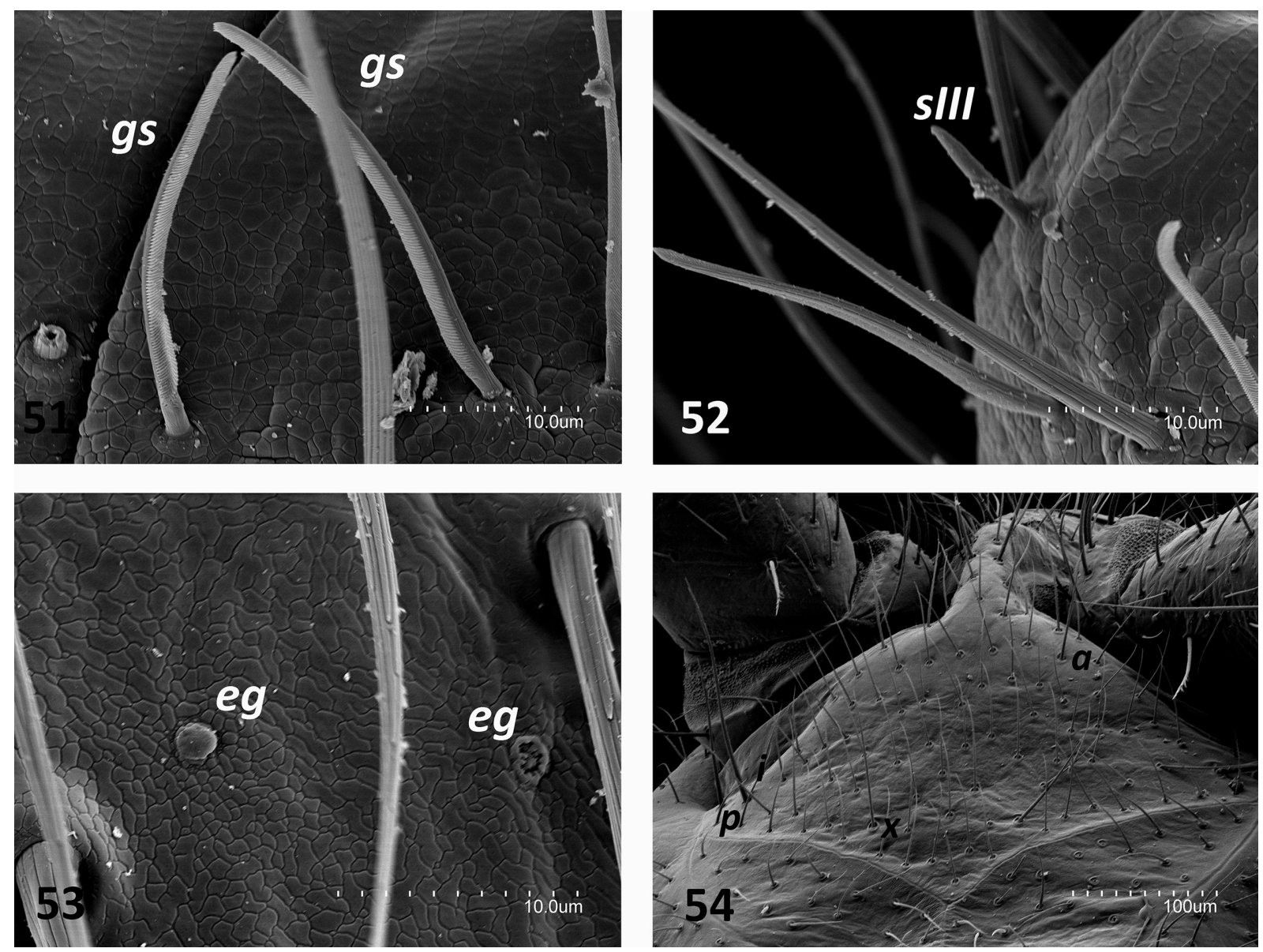

Figs 51-54. Pacificampa wudonghuii Sendra sp. nov. 51. Gouge sensilla $(g s)$ of antennomeres. 52. Sensillum of the third antennomeree $(s I I I)$. 53. Surface of the notum with external glands $(\mathrm{eg})$. 54. Frontal process with anterior $(a)$, intermediate $(i)$ and posterior $(p)$ macrosetae of the insertion line of antennae and $x$ setae. 
SECONDARY SEX CHARACTERS. Female urosternite I with subcylindrical appendages, each bearing up to 40 glandular $a 1$ setae in apical field. Male urosternite I with thick short, and subcylindrical appendages, each with large apical field of about 220 glandular $a 1$ setae (Fig. 62).
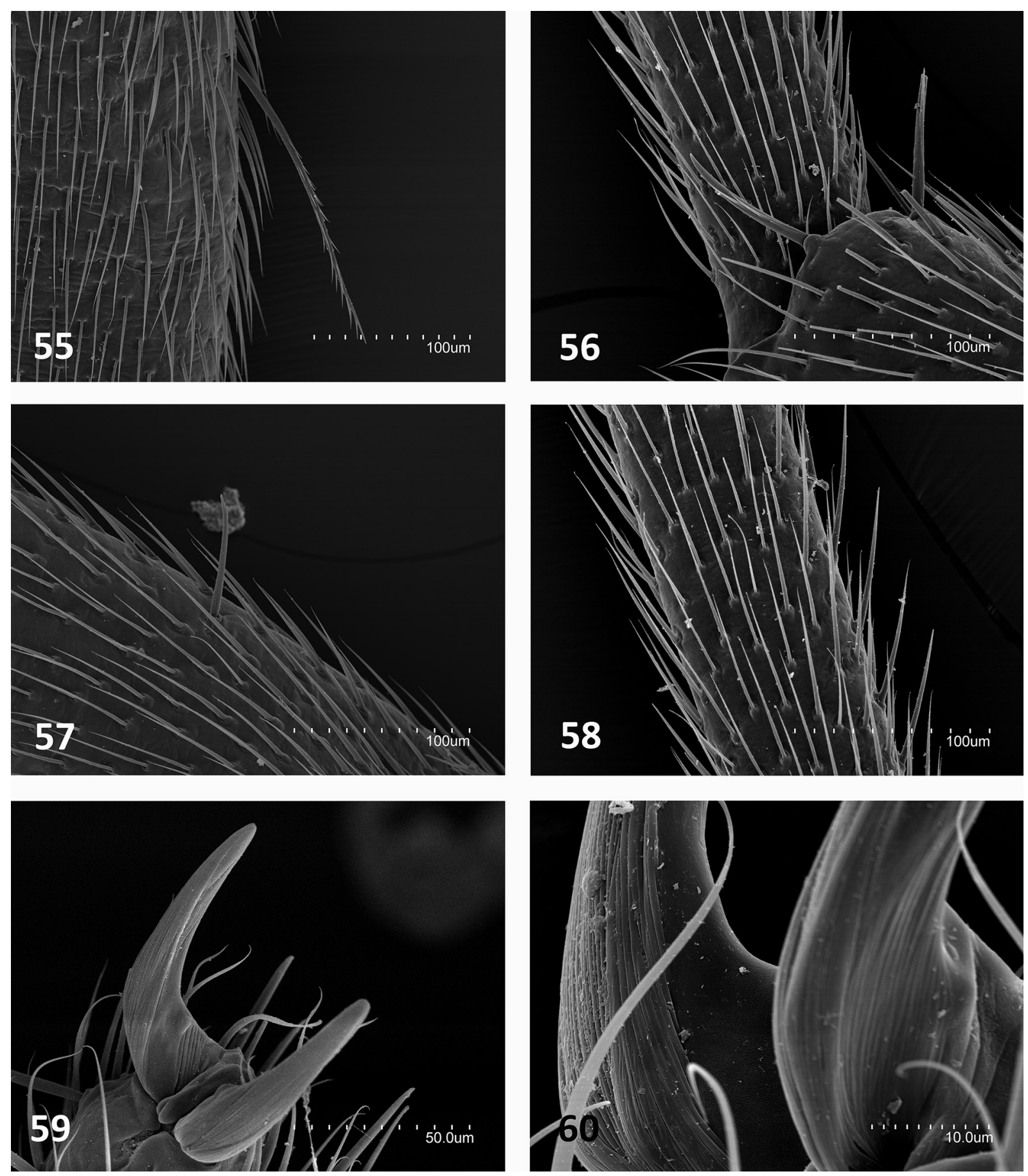

Figs 55-60. Pacificampa wudonghuii Sendra sp. nov. 55. Dorsal macrosetae on the metathoracic femur. 56. Joint between tibia and tarsus with calcars. 57. Ventral macroseta on the tibia. 58. Lateral side of the tarsus. 59. Pretarsus. 60. Detail of the pretarsus. 

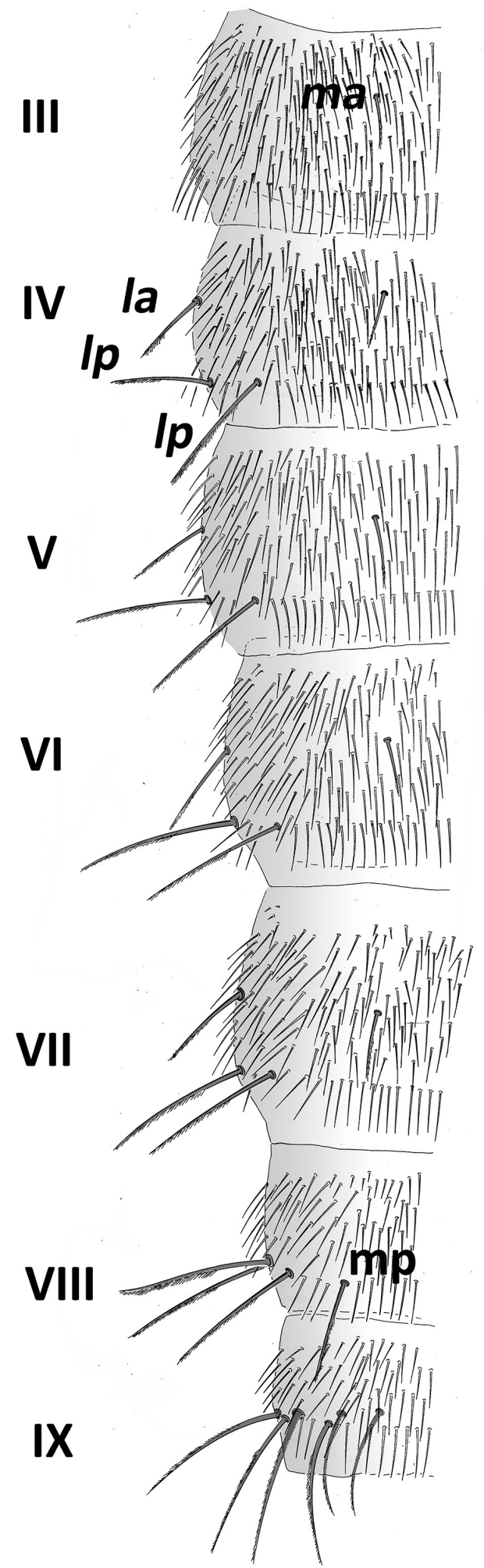

61

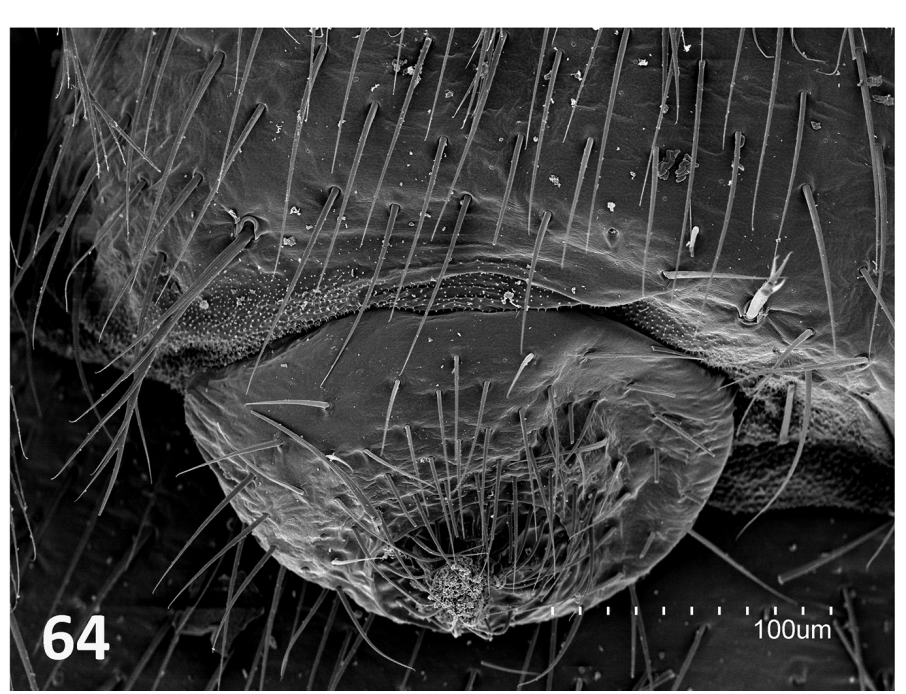

Figs 61-64. Pacificampa wudonghuii Sendra sp. nov. 61. Urotergites III-VIII and IX abdominal segment, left side (holotype, NEIGA-diplura-01). 62. Male first urosternite with glandular $a_{1}$ setae. 63. Fourth urosternite, right side. 64. Male eighth urosternite.
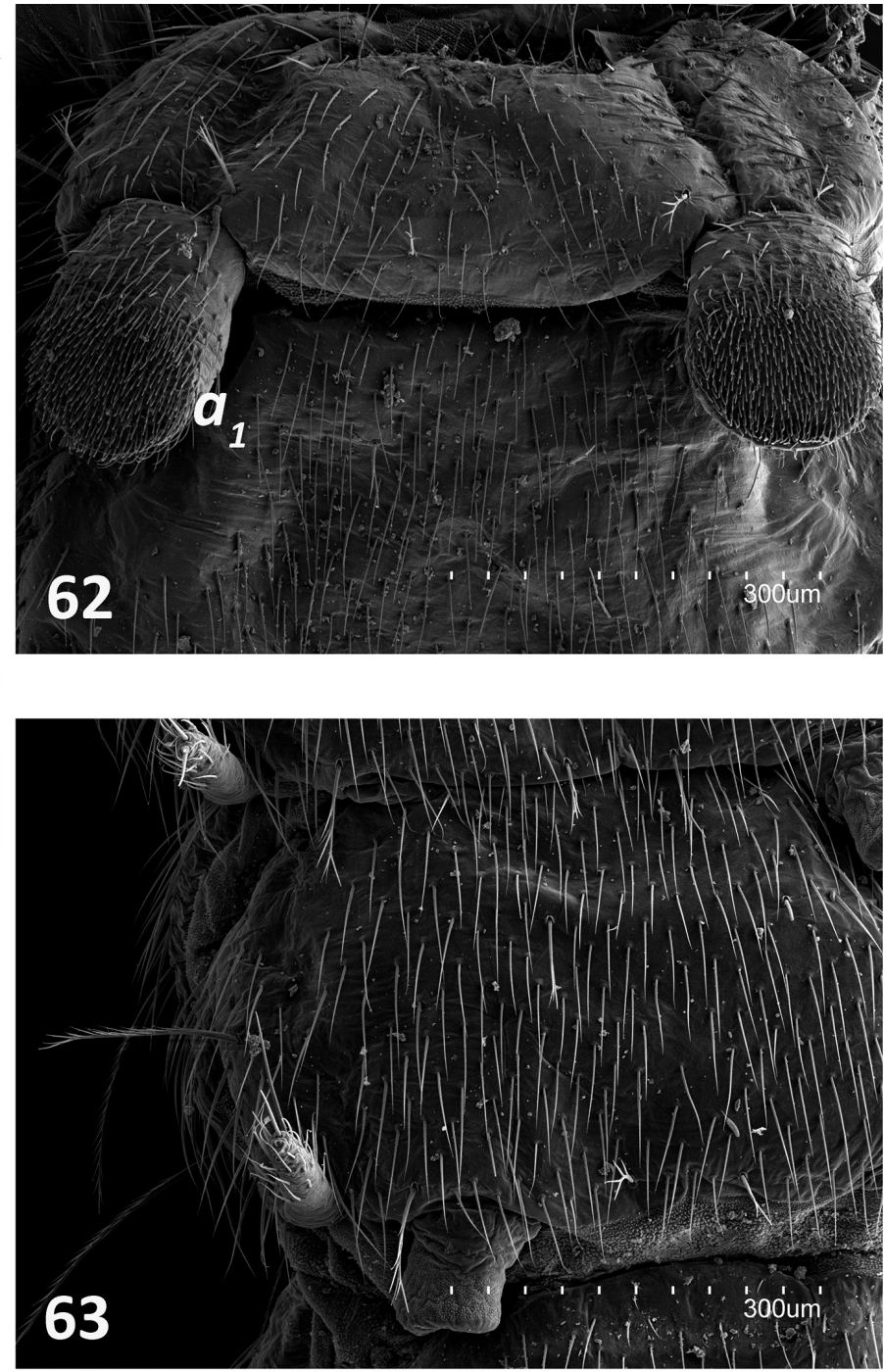


\section{Taxonomic affinities}

Pacificampa wudonghuii sp. nov. shares with P. birsteini Chevrizov, 1978, P. caesa Chevrizov, 1978 and P. nipponica Sendra, 2018 the same distribution of notal macrosetae (1+1 medial anterior, 1+1 lateral anterior, and 1+1 lateral posterior macrosetae on pronotum; $1+1$ medial anterior, $1+1$ lateral anterior, and 2+2 lateral posterior macrosetae on mesonotum; and 1+1 medial anterior and 1+1 lateral anterior macrosetae on metanotum). An undescribed species mentioned by Ferguson (1997) from northeastern China also has this setal distribution. However, $P$. wudonghuii sp. nov. differs from other species of Pacificampa in having 1+1 medial anterior, 1+1 lateral anterior, and 2+2 lateral posterior macrosetae on the fourth urotergite (Fig. 61), a pattern distribution that begins on the fifth urotergite for the other species. In addition, the larger male appendages have more abundant glandular $a_{1}$ setae in $P$. wudonghuii sp. nov. (Fig. 62) than in the other species of Pacificampa.

\section{Pacificampa sp.}

\section{Material examined}

CHINA • 1 immature $\widehat{\partial}(6.1 \mathrm{~mm}), 1$ juvenile $(5.9 \mathrm{~mm})$; Jilin Province, Tonghua, Ji'an, Zhi An Cave; 16 May 2019; Deharveng and Bedos leg.; CHIJL19-008.

\section{Taxonomic notes}

The distribution of notal and urotergal macrosetae on the immature male is the same as that of P. birsteini Chevrizov, 1978 and P. caesa Chevrizov, 1978. However, urosternite I has 7+7 macrosetae and II-VII have $4+4$ macrosetae, instead of $6+6$ and $5+5$ macrosetae as in P. birsteini and P. caesa.

Suborder Dicellura Cook, 1899

Family Japygidae Haliday, 1864

Mueggejapyx Sendra \& Komerički gen. nov. urn:1sid:zoobank.org:act:924B9ABA-1630-4832-86EE-19CE73C3E7CB

\section{Type species}

Mueggejapyx brehieri Sendra \& Komerički gen. et sp. nov.

\section{Diagnosis}

Large and elongated body; antennae with 36 antennomeres; trichobothria on antennomeres 4-6 in a 3/5/5 pattern; $a$ trichobothria in distal position; $1-2$ placoid sensilla on medial and distal antennomere; apical antennomere with 16-18 placoid sensilla; dorsal and ventral side of head with numerous uniformly distributed sM and sm, and several M; five laminae pectinate on maxilla; elongated thoracic segments; and cuticle with tiny micro-holes, pronotum and mesonotum each with $5+5 \mathrm{M}$, metanotum with 2+2 M; strong internal Y cuticular furcisternite structures in pro-presternites and pro-, meso- and metasternites; urotergites with at most $1+1 \mathrm{M}(m a), 1+1 \mathrm{M}_{1}, 1+1 \mathrm{M}_{2-5}$; urite $\mathrm{X}$ longer than wide, with marked carinae with subparallel margins, with $2+2$ intracarinal macrosetae; acropygium rounded; lateral angles of urotergites VI and VII with weakly to moderate lobiform projection; first urosternite with multiperforated surface and rounded protrusions, with $3+3 \mathrm{M}$ on prescutum and $11+11 \mathrm{M}$ on scutum; median glandular organ with seta-shaped sensilla; lateral subcoxal organs with one to three rows of short glandular setae (GS), one row of sensory setae (SS), and a row of setae with large socket; sternites with abundant sm and strong M; cerci strong, elongated, rectilinear and becoming curved subapically, heavily sclerotized with external dorsal and ventral carinae. Both cerci without medial tooth, but with one short row of small round denticles on the right cercus and two rows of small round denticles on the left cercus. 


\section{Etymology}

This genus is dedicated to the memory of the American entomologist Mark Alan Muegge (pronounced Meggy), who died young due to an unfortunate car accident in 2015. He left behind a promising career and was devoted, among other groups, to diplurans; alongside other taxa, he provided a description of the highly cave-adapted japygid from Texas, Mixojapyx reddelli Muegge, 1992.

Mueggejapyx brehieri Sendra \& Komerički gen. et sp. nov. urn:1sid:zoobank.org:act:8D581345-0B2E-4E5C-918C-DBF84F3B6978

Figs 2, 65-97; Tables 5-6

\section{Etymology}

This species is dedicated to Franck Brehier, French biospeleologist, who has dedicated himself to exploring and studying many karst areas and caves in Southeast Asia.

\section{Type material}

\section{Holotype}

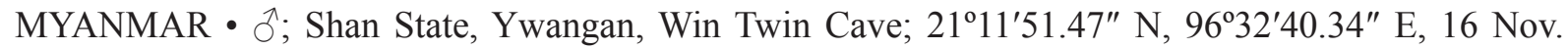
2018: Aung Lin leg.; labelled “ $\$$-holotype"; MZB (MCNB) 2020-1156.

\section{Paratypes}

MYANMAR • $1 \hat{\jmath}, 1$ क; same collection data as for holotype; labelled " $\hat{\jmath} 3$-paratype" and " $\bigcirc 1-$ paratype"; MZB (MCNB) 2020-0626, MZB (MCNB) 2020-0627 • 1 क; same collection data as for holotype; labelled "O+2-paratype"; MZB (MCNB) 2020-1159 • 1 đo; Shan State, Parpent Cave 1; 2 Dec. 2015; Franck Brehier leg; collected by hand; collector's code BUR15-FB20; labelled " $\lesssim 5$-paratype"; MZB (MCNB) 2020-0628 • 1 ó; same collection data as for preceding; collector's code MY15-20.06; labelled “ `7-paratype”; MZB (MCNB) 2020-1158 • 1 \%; Shan State, Kyauk Khaung [= Stone Cave]; 30 Nov. 2015; Franck Brehier leg.; collector’s codes: BUR15-FB17, MY15-17.03; labelled “+ 6-paratype”; MZB (MCNB) 2020-1157.

\section{Other material examined}

MYANMAR • 2 specs; same collection data as for holotype; mounted on two separate aluminium stages and coated with palladium-gold; Coll. AS.

\section{Description}

Body. Elongated (Fig. 2), length $23 \mathrm{~mm}$ in male holotype (19-26 mm in three paratype females, $15-23 \mathrm{~mm}$ in three paratype males). Greatest width at urotergite VII $2.6 \mathrm{~mm}$. Epicuticle smooth under optical microscope, with numerous micropores at higher magnifications (Figs 72, 85). Cuticle unpigmented, except for slightly sclerotized areas on dorsal head, mandible tips, femoral and tibial condyles and segments VI-X (Fig. 2).

HEAD. Antennae with 36 antennomeres; antennae less than $1 / 2$ body length; first antennomere short, followed by three longer and larger antennomeres ( $2^{\text {nd }}$ to $4^{\text {th }}$ antennomeres with reinforced borders) (Figs 65-68, 70; Table 5). All antennomeres with abundant setae including sM and sm setae, which appear more abundant on ventral side of $7^{\text {th }}$ to $16^{\text {th }}$ antennomeres under light microscope; trichobothria present on antennomeres 4-6 in a 3/5/5 pattern, in which $a$ trichobothria in distal position; 1 or 2 placoid sensilla present on latero-interior ventral side on $17^{\text {th }}$ and more distal antennomeres; apical antennomere bearing 16-18 placoid sensilla distributed in three irregular whorls (Figs 65-66). Dorsal and ventral side of head with numerous uniformly distributed sM and sm, and several $\mathrm{M}$, more obvious in young 
specimens ( 37 -paratype); on dorsal side A1-3, S2,4,6, M2,3,5, I4,5, P2 and L1-5 (Fig. 69); on ventral side, submentum with large $1+1 \mathrm{M}$ in posterior position, admentum with $4+4 \mathrm{M}$, mentum at base of labial palps with $1+1 \mathrm{M}$; external lobes of mentum with abundant sM; internal lobes with $1+1$ short $\mathrm{M}$. Elongated, conical labial palps almost $3 \times$ as long as wide compared with sM and sm in addition to one
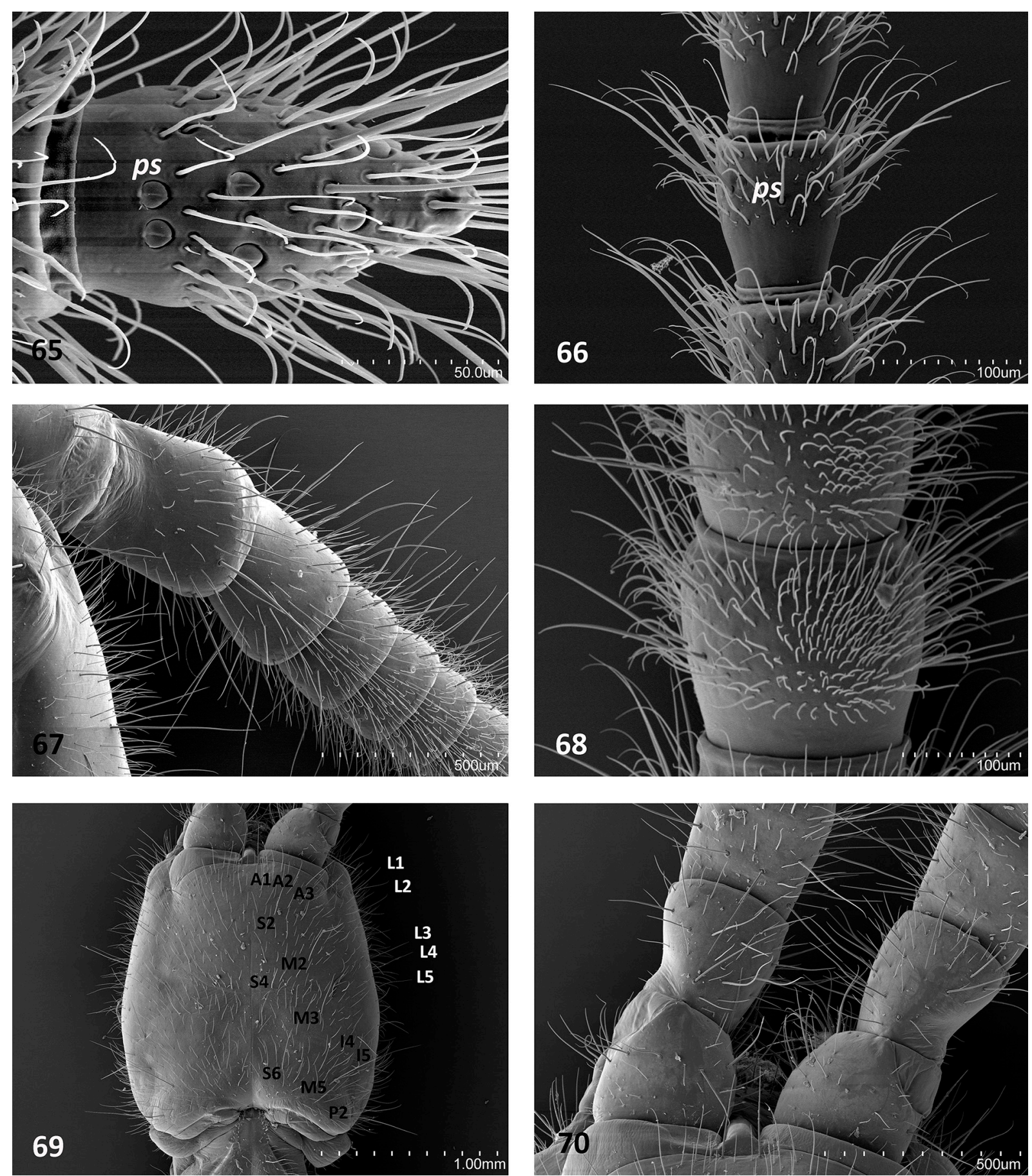

Figs 65-70. Mueggejapyx brehieri Sendra \& Komerički gen. et sp. nov. 65. Last antennomere with placoide sensilla $(p s)$. 66. Distal antennomeres with placoide sensilla $(p s)$. 67. Central antennomeres. 68. Proximal antennomeres, ventral side. 69. Head, dorsal side. Abbreviations: see Material and methods. 70. Proximal antennomeres, dorsal side. 
Table 5. Mueggenjapyx brehieri Sendra \& Komerički gen. et sp. nov., length of the body, antennae and femur, tibia and tarsus of the metathoracic leg (all units in mm except number of antennomeres). $*=$ telescoped antennomeres.

\begin{tabular}{|c|c|c|c|c|c|c|c|}
\hline Specimen & $\begin{array}{r}\text { Body } \\
\text { length }\end{array}$ & $\begin{array}{c}\text { Antenna } \\
\text { length }\end{array}$ & Antennomeres & Femur & Tibia & Tarsus & Cerci \\
\hline ふ7-paratype (MZB (MCNB) 2020-1158) & 15 & 4.1 & 36 & 1.1 & 1.0 & 0.9 & 1.4 \\
\hline 万3-paratype (MZB (MCNB) 2020-0626) & 16.5 & 5.5 & 36 & 1.6 & 1.6 & 1.3 & 2.0 \\
\hline q6-paratype (MZB (MCNB) 2020-1157) & 19 & 7.2 & 36 & 1.8 & 1.8 & 1.6 & 2.1 \\
\hline q2-paratype (MZB (MCNB) 2020-1159) & 21 & - & - & 1.8 & 1.7 & 1.5 & 2.4 \\
\hline స5-paratype (MZB (MCNB) 2020-0628) & 21 & $6.6^{*}$ & 36 & 1.9 & 1.7 & 1.6 & 2.3 \\
\hline 4-holotype (MZB (MCNB) 2020-1156) & 23 & $5.8^{*}$ & 36 & 2.3 & 2.1 & 1.8 & 2.7 \\
\hline 1-paratype (MZB (MCNB) 2020-0627) & 26 & $6.1^{*}$ & 36 & 2.6 & 2.5 & 2.3 & 2.8 \\
\hline
\end{tabular}

long, apical seta and a few shorter setiform sensilla (Figs 75-77). Lacinia falciform well sclerotized, all five laminae pectinate.

Thorax. Thoracic segments elongated (Figs 71, 75). Pronotum with 5+5 $\mathrm{M}$ and numerous uniformly distributed sM and sm; mesonotum with $5+5 \mathrm{M}$ and a few sM and sm; metanotum with $2+2 \mathrm{M}$ and a few sm; both prescuta have $1+1 \mathrm{M}$ and scattered sM and sm; at high magnifications tiny, uniformly distributed micropores $(0.10-0.15 \mu \mathrm{m}$ diameter) visible on cuticle surface (Fig. 72). Thoracic sternites, intersternites, and presternites well defined with sm, sM, and M setae (Figs 75, 77-79). Pro-presternites and pro-, meso- and metasternites have strong internal Y-shaped cuticular structures (furcisternites) (Barlet \& Carpentier 1962), and only in pro-presternites prolongation of posterior branch named spine clearly visible on surface (Denis 1949). Pro-presternum with $1+1$ short $M$ in anterior lateral position and $1+1 \mathrm{sM}$ in medial anterior; prosternum with $1+1$ medial anterior $\mathrm{M} ; 3+3$ lateral anterior $\mathrm{M}, 1+1$ medial intermediate $\mathrm{M}$ and $2+2$ lateral posterior $\mathrm{M}$; meso-poststernum with $5+5 \mathrm{M}$; meso-intersternum with $5+5 \mathrm{M}$; mesosternum with $1+1$ medial anterior $\mathrm{M}, 4+4$ lateral anterior $\mathrm{M}, 1$ $M$ sagittal, $1+1$ medial intermediate $M, 1+0$ medial posterior $M$ and $3+3$ lateral posterior $M$; metapoststernum with $5+5 \mathrm{M}$; meta-intersternum $4+4 \mathrm{M}$; and metasternum with $1+1$ medial anterior $\mathrm{M}$, 3+3 lateral anterior $M ; 1+1$ sagittal $M, 1+1$ medial intermediate $M, 3+3$ lateral posterior $M$ (Figs 75 , 77-79). Legs elongated, hind legs reaching $5^{\text {th }}$ abdominal segment. Frictional setae between trochantercoxa-femora articulations; femora-tibia-tarsus articulations with row of long $\mathrm{M}$ or sM setae with large sockets, plus additional $1 \mathrm{M}$ in coxa, $5 \mathrm{M}$ in trochanter and $7 \mathrm{M}$ in femora. Tibia and tarsus with $\mathrm{M}$ and $\mathrm{sM} ; 5 \mathrm{M}$ in tibia and $2 \mathrm{M}$ in tarsus. Tibia also bearing one calcar seta at ventral apex, thicker and more robust than other tibial setae, and two rows of four or five thick setae along ventral side. Pretarsus with two unequal claws and sharp medial unguiculus.

AbDomen. Abdominal tergites with few sm and sM. Tergite I (prescutum and scutum) without M; tergite II with 0 or $1+1 \mathrm{M} 5$; tergite III with $1+1 \mathrm{M}$ (medial anterior macrosetae), 0 or $1+1 \mathrm{M} 1,1+1 \mathrm{M} 4-5$; tergites IV-VI with 1+1 M (ma), 0 or 1+1 M1, 1+1 M2-5; tergite VIII with 1+1 M4-5; tergite IX lacking M except (M1 present in specimens from Parpent Cave 1 (Fig. 88). Urite X (Figs 89, 92) nearly $1.5 \times$ as long as wide, distinctly marked carinae present with subparallel margins slightly convergent towards posterior; $2+2$ intracarinal D1 and D3 macrosetae and 3+3 macrosetae (L1, L3, L5) on carinae (Fig. 89); ventral side with four rows of $3+3 \mathrm{M}, 3+3 \mathrm{M}, 2+2 \mathrm{M}$, and $2+2 \mathrm{M}$ from anterior to posterior position; acropygium rounded (Fig. 91). Tergites I-V with blunt, slightly rounded to pointed posterolateral angles; angles on tergites VI and VII more conspicuous, lobiform projection small to more prolonged 


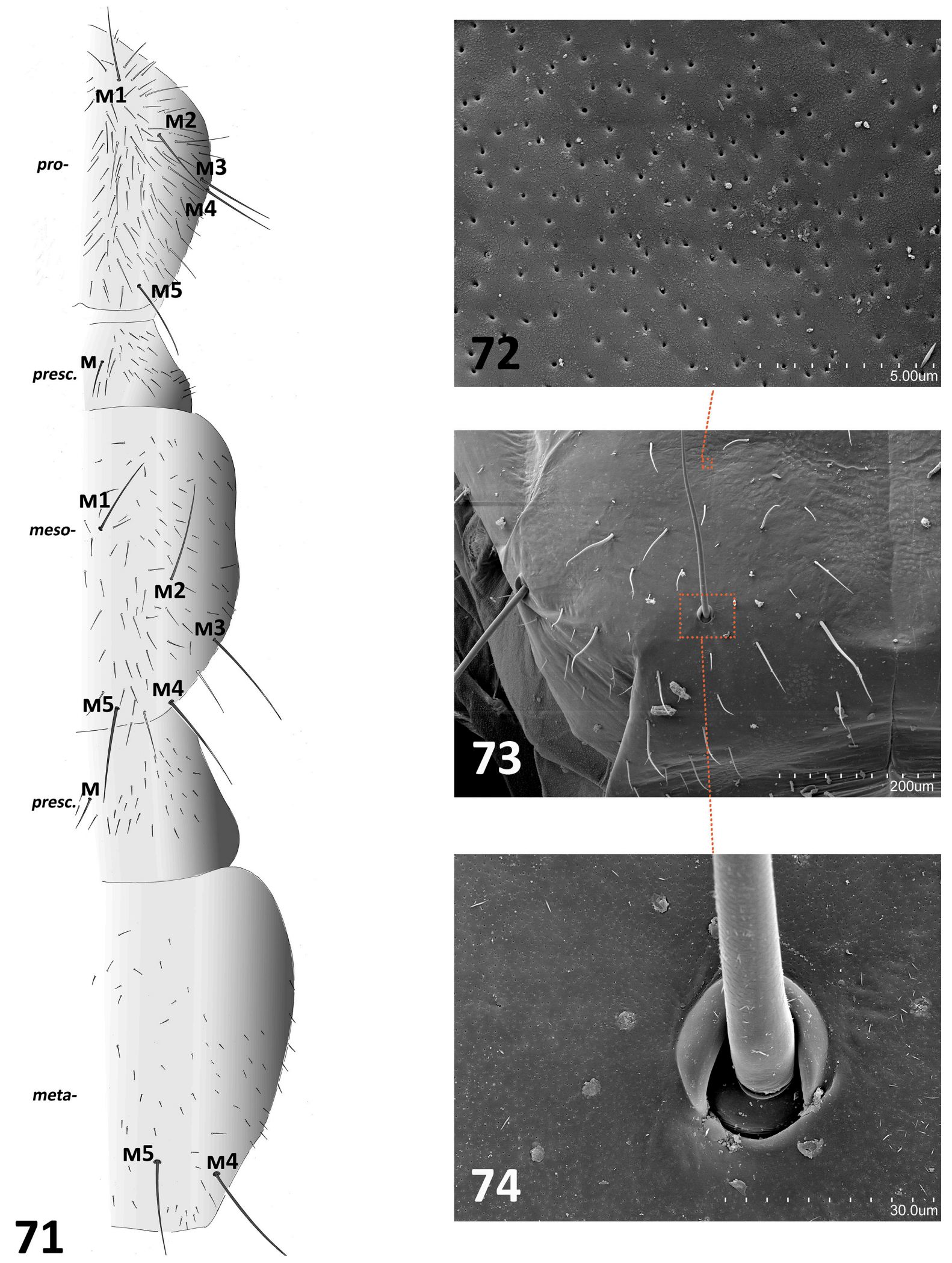

Figs 71-74. Mueggejapyx brehieri Sendra \& Komerički gen. et sp. nov. 71. Pronotum, mesonotum and metanotum, right side, see terminology in the text (holotype, MZB (MCNB) 2020-1156). 72. Detail of the surface of the mesonotum. 73. Detail of the latero-posterior left side of the mesonotum. 74. Detail of the macroseta base. 


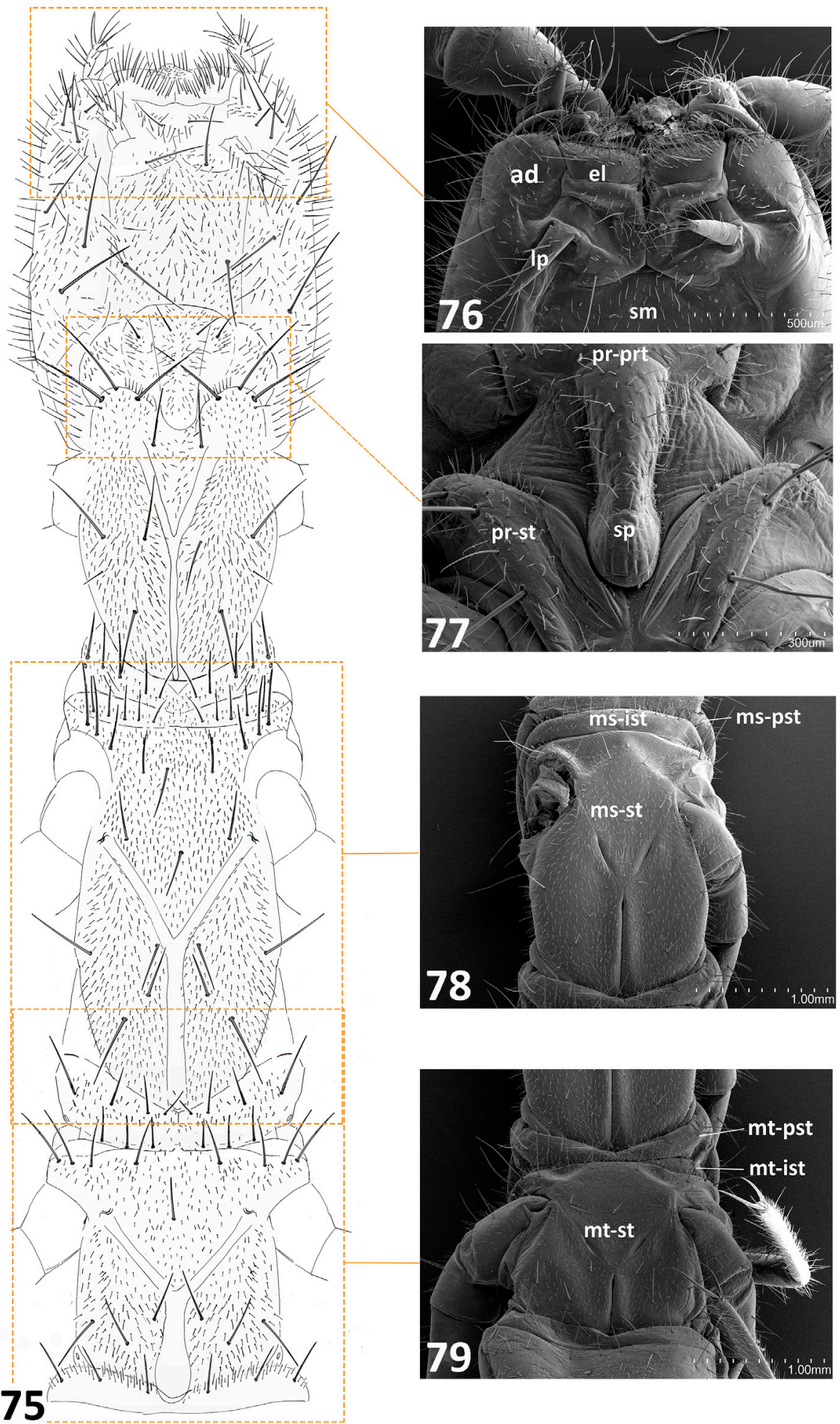

Figs 75-79. Mueggejapyx brehieri Sendra \& Komerički gen. et sp. nov. 75. Head, prothorax, mesothorax and metathorax, ventral view (paratype, MZB (MCNB) 2020-1157). 76. Head anterior ventral side, (ad) admentum, (el) external lobule, (lp) labial palp, and (sm) submentum. 77. Pro-prosternum (pr-prt) with spine (sp) and anterior portion of prosternum (pr-st). 78. Meso-poststernum (ms-pst), meso-intersternum (ms-ist), and mesosternum (ms-st). 79. Meta-poststernum (mt-pst), meta-intersternum (mt-ist), and metasternum (mt-st). 
and visibly sclerotized in largest specimens; tergite IX with projections (Fig. 88). Sternite I (Figs 80-85) with multiperforated surface and rounded protrusions covered by abundant sm and lesser sM and 3+3 or $3+4 \mathrm{M}$ on prescutum and $11+11 \mathrm{M}$ on scutum. Median glandular organ with 12 seta-shaped sensilla (Fig. 83). Lateral subcoxal organs invaginated below posterior margin or evaginated showing central
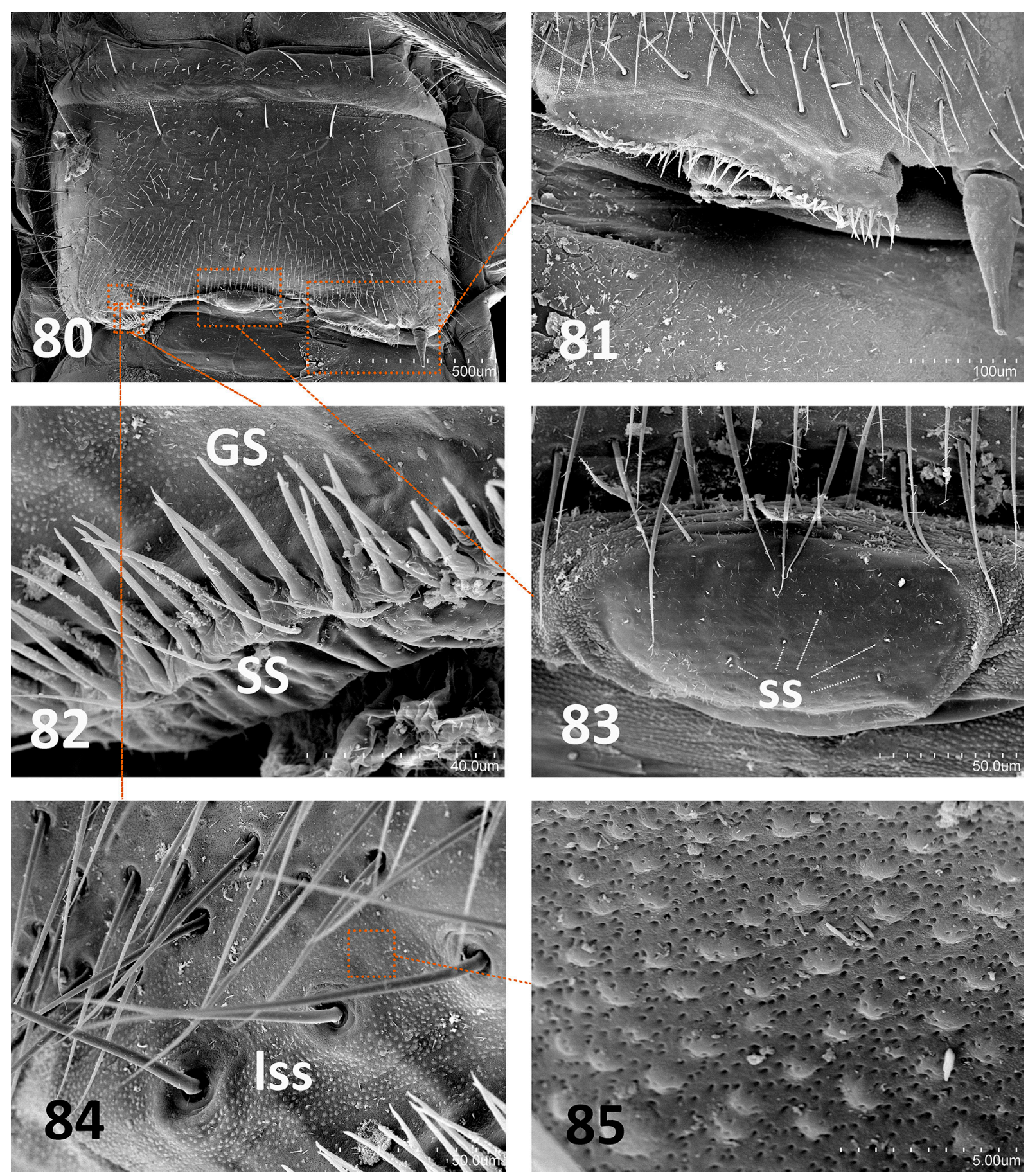

Figs 80-85. Mueggejapyx brehieri Sendra \& Komerički gen. et sp. nov. female. 80. First urosternite. 81. Lateral posterior of the first urosternite. 82. Detail of the lateral coxal organ with glandular setae (GS) and setiform setae (SS). 83. Median glandular organ (ss: setae-shaped sensilla). 84. Detail of the large socket setae (lss) of the lateral coxal organ. 85. Detail of the cuticle of the first urosternite. 
opening protruding over margin of first urosternite (Figs 81-82). Each lateral subcoxal organ with one, two, or three rows of glandular setae (GS) (54-100 in males, 47-66 in females) and one row of sensory setae (SS) (11-24 in males, 13-15 in females) occupying 0.22-0.30 (males) and 0.23-0.25 (females) of interstyle width; GS/st1 (stylus of first sternite) $=0.1-0.23$ (males) and $0.18-0.28$ (females), SS/st $1=$ 0.19 (male) and $0.16-0.26$ (females); row of setae with large sockets anterior to glandular setae, 7-12
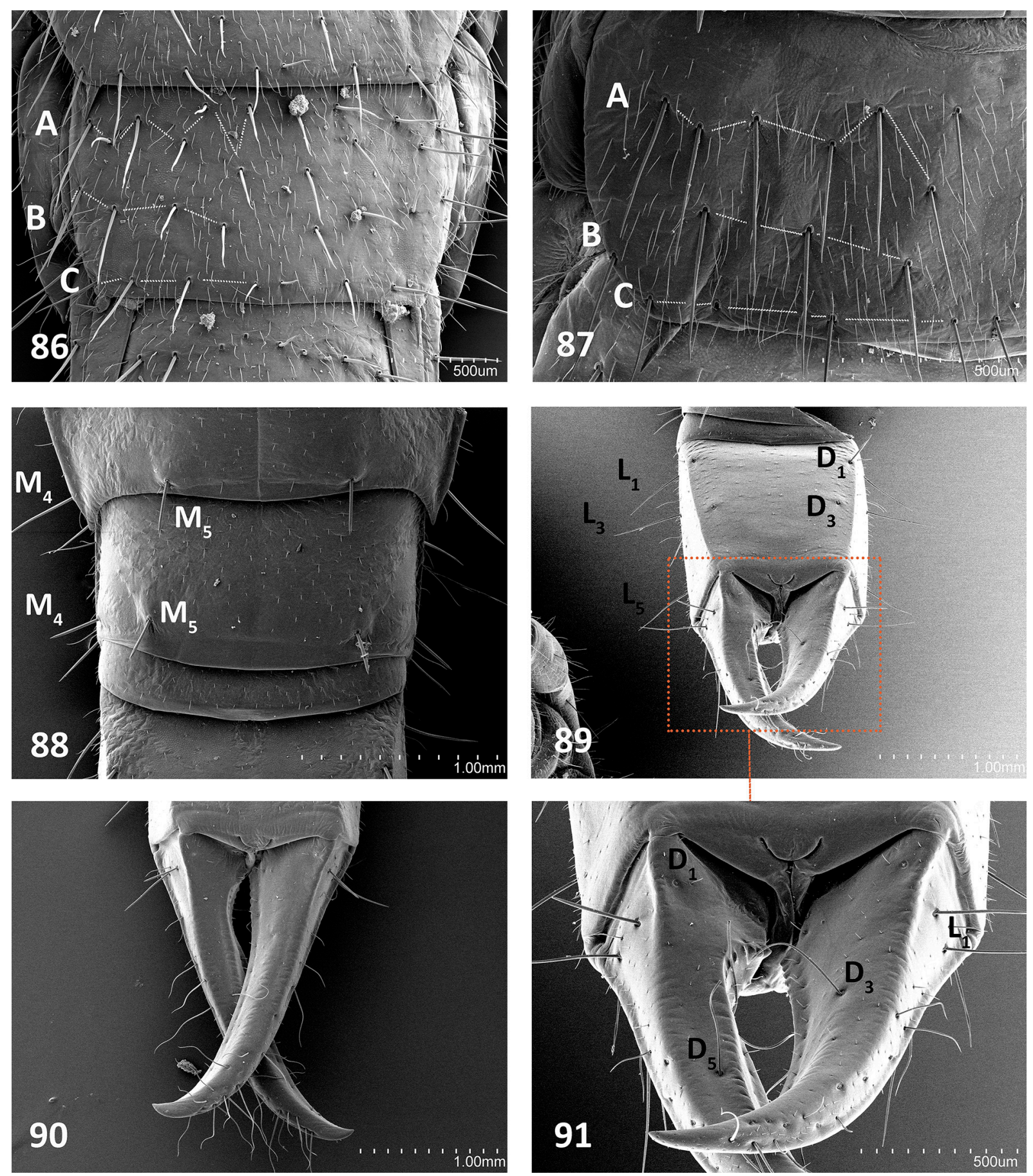

Figs 86-91. Mueggejapyx brehieri Sendra \& Komerički gen. et sp. nov. 86. Eighth and ninth urosternites. 87. Fourth urosternite. 88. Eighth and ninth urotergites. 89. Urite $X$ and cerci, dorsal side. 90. Cerci, dorsal side. 91. Detail of the cerci, dorsal side. Abbreviations: see Material and methods. 
in males and 6-10 in females (Figs 80-85). Sternites have abundant sm and strong M; sternites II-VII with 7+7 A M, 5+5 (4+4) B M and 4+4 C M; sternite VIII with 3+3 (4+4) A M, 3+3 (2+2) B M and 3+3 C M (see Material and methods for terminology); sternite IX with 1+1 M (Figs 86-87). Cerci strong, well developed, elongated and rectilinear, becoming curved toward apex (Figs 89-92), length ranging
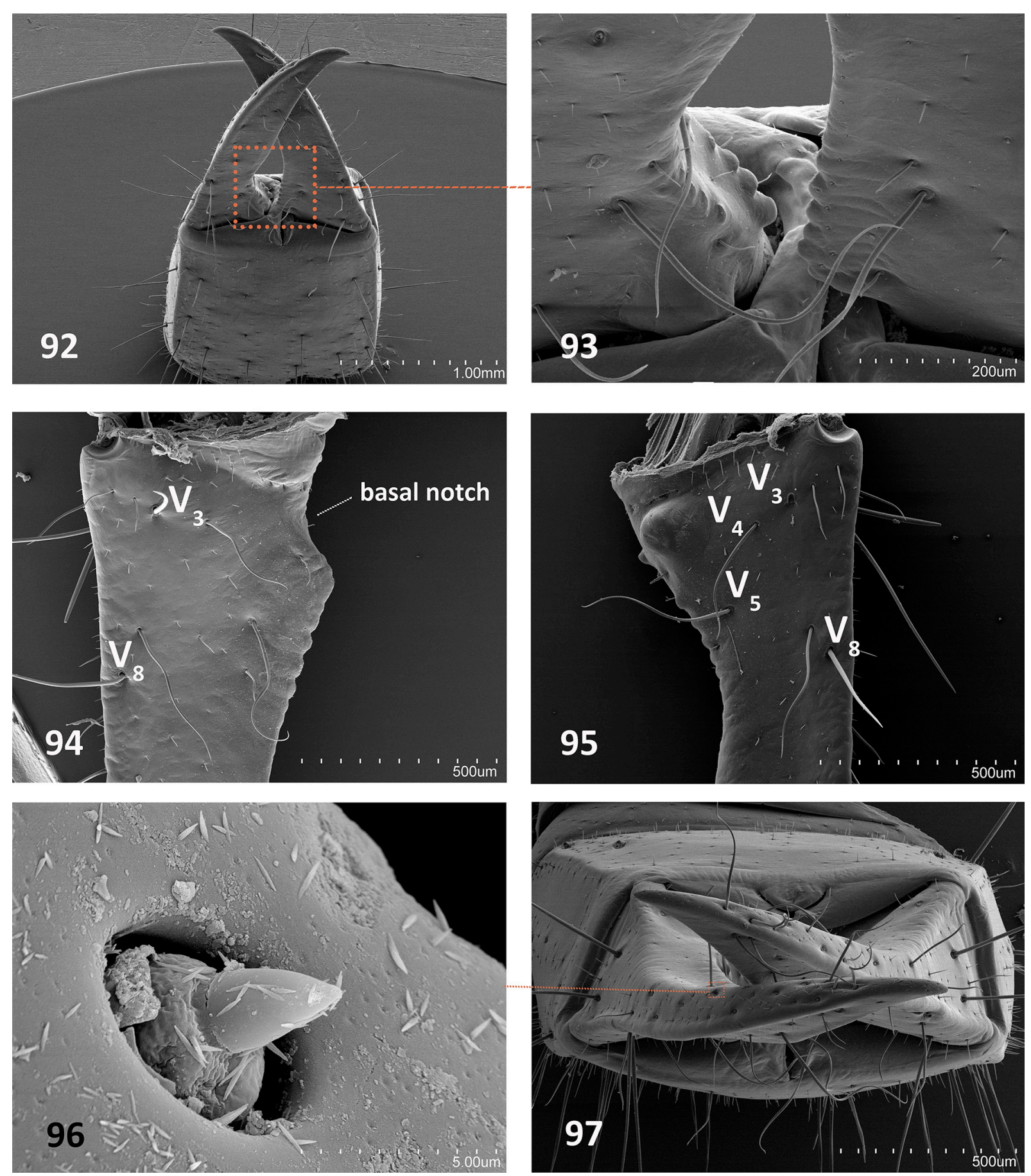

Figs 92-97. Mueggejapyx brehieri Sendra \& Komerički gen. et sp. nov. 92. Urite X and cerci, ventral side. 93. Proximal and ventral side of the cerci. 94. Ventral proximal portion of the left cercus. 95. Ventral proximal portion of the right cercus. 96. Conical sensillum of the cerci. 97. Cerci, caudal view. See Material and methods for terminology. 
Table 6. Mueggenjapyx brehieri Sendra \& Komerički gen. et sp. nov., subcoxal organs with number of glandular, sensory setae and large socket setae including body, interstylar width-length in $\mathrm{mm}$ and index of GS/st1 and SS/st1.

\begin{tabular}{|c|c|c|c|c|c|c|c|}
\hline \multirow[b]{2}{*}{ Specimen } & \multirow[b]{2}{*}{$\begin{array}{l}\text { Body } \\
\text { length }\end{array}$} & \multicolumn{6}{|c|}{ Subcoxal organs } \\
\hline & & $\begin{array}{l}\text { Glandular } \\
\text { setae (GS) }\end{array}$ & $\begin{array}{c}\text { Sensory } \\
\text { setae (SS) }\end{array}$ & $\begin{array}{c}\text { Rows of setae } \\
\text { length/interstylar } \\
\text { width }\end{array}$ & $\begin{array}{c}\text { Setae of } \\
\text { large socket }\end{array}$ & GS/st1 & SS/st1 \\
\hline J7-paratype (MZB (MCNB) 2020-1158) & 15 & 54 & 11 & 0.22 & 7 & 0.23 & 0.19 \\
\hline 33-paratype (MZB (MCNB) 2020-0626) & 16.5 & 57 & 24 & 0.30 & 6 & - & - \\
\hline \$5-paratype (MZB (MCNB) 2020-0628) & 21 & 115 & - & 0.24 & 13 & 0.17 & - \\
\hline 34-holotype (MZB (MCNB) 2020-1156) & 23 & 100 & - & 0.27 & 12 & 0.22 & - \\
\hline q6-paratype (MZB (MCNB) 2020-1157) & 19 & 47 & - & 0.23 & 6 & 0.21 & - \\
\hline q2-paratype (MZB (MCNB) 2020-1159) & 21 & 60 & 13 & 0.23 & 5 & 0.28 & 0.26 \\
\hline 1-paratype (MZB (MCNB) 2020-0627) & 26 & 66 & 15 & 0.25 & 10 & 0.18 & 0.16 \\
\hline
\end{tabular}

from $2.8 \mathrm{~mm}$ in largest specimen ( 1 -paratype) to $1.4 \mathrm{~mm}$ in the smallest ( 7 -paratype); cerci always slightly longer than urite $\mathrm{X}$, heavily sclerotized with external dorsal andventral carinae projecting from dorsal and ventral acetabular articulations running almost to apex ventrally and halfway dorsally. Cerci with medial tooth; right cercus with basal notch complementary in shape to round tooth at ventral side of basal portion of left cercus. Posterior to right notch and left tooth: in right cercus short row of 5 or 6 small, round denticles in line; and in left cercus two rows of small round denticles $(4+4)$; these rows of denticles occupying $1 / 8$ of total length of each cercus (Figs 89-95, 97). Each cercus with scattered sm, $\mathrm{sM}$, and $\mathrm{M}$ setae and several conical sensilla throughout, more abundant distally (Figs 96-97). Dorsal side of each cercus with 6 or 7 D macrosetae, D1, D3 and D5 largest on both cerci; ventral side with 12 V-macrosetae, V3 and V8 being largest; intracarinal region with 5-7 L macrosetae, a pair of macrosetae in L1 being largest (Figs 91, 94-95).

\section{Taxonomic affinities}

Mueggejapyx gen. nov. is distinguished by its elongated, rectilinear, heavily sclerotized cerci curving subapically, and lacking a medial tooth but with one or two rows of basal small round denticles, its median glandular organ with seta-shaped sensilla, and short lateral subcoxal organs, each with a row of setae that have large sockets.

\section{Remarks}

Mueggejapyx brehieri gen. et sp. nov., was observed and collected along with A. ywangana sp. nov. in Win Twin Cave (Figs 1-4), as well as in two nearby caves: Parpent Cave 1 and Kyauk Khaung (synonyms: Sin Lae Ye Win, Stone Cave). The latter is the second longest cave so far explored in Myanmar. Kyauk Khaung Cave is over $4790 \mathrm{~m}$ long and also situated in the Ywangan karst area. Its entrance is located only $1240 \mathrm{~m}$ southeast of the entrance to Win Twin, and the cave itself extends mostly towards the northeast of the entrance. During the 2015 biological research of Kyauk Khaung, specimens of Campodeidae and Japygidae were found in the northernmost parts of the cave, which indicates the species is most likely distributed throughout the entire subterranean habitats of the Ywangan karst (unpublished data). The Ywangan karst covers 1050 ha, and at the moment hosts three other endemic troglobitic invertebrates: the carabid beetle Birmaphaenops brehieri Deuve, 2017 (Deuve 2017), the cave crab Shanphusa ywarngan Ng \& Whitten, 2017 (Ng \& Whitten 2017), and a woodlouse Bamaoniscus lobatus Taiti et al, 2020 as well as an endemic karst-adapted gecko, the Linn-Way bent-toed gecko Cyrtodactylus linnwayensis Grismer et al., 2017 (Grismer et al. 2017), and 17 species of bats (unpublished data). Due to its biodiversity, Ywangan karst is proposed as a karst Key Biodiversity Area and a subterranean 
Ramsar Site. Although cave tourism is being developed in the area, there are substantial efforts being made by the NGO sector (Fauna \& Flora International Myanmar) to provide guidance for development of sustainable, low-impact tourism as well as cave and biodiversity conservation (unpublished data).

\section{Discussion}

\section{Morphological and taxonomic affinities}

Based on the latest results, Campodeidae has 142 described species inhabiting only caves (30\%), while Japygidae has 9 (2\%) (Bareth \& Pagés 1994).

The most diverse campodeid subfamilies are Campodeinae Condé, 1956, Plusiocampinae Paclt, 1957 and Lepidocampinae Condé, 1956. When Lepidocampinae is characterized by macrosetae modified in scales, Campodeinae and Plusiocampinae species have simple macrosetae with barbs, while Lepidocampinae is scaled. Campodeinae is defined by the presence of no more than $3+3$ pronotal macrosetae and mostly simple claws, whereas Plusiocampinae is defined by having at least $4+4$ macrosetae and elbowed claws usually possessing lateral crests (Condé 1956).

Campodeinae has only one cave genus, Pacificampa, with five species: two in the extreme east of Siberia (Chevrizov 1978); two on the Japanese islands of Kyushu and Shikoku (Sendra et al. 2018) and P. wudonghuii sp. nov. from northeastern China. All five species have in common their peculiar enlarged dorsal ridged claws without pretarsus lateral processes (Figs 59-60), similarities in the distribution of the macrosetae in the thorax and abdomen, as well as the absence in both sexes of glandular $g_{l}$ setae on the posterior border of the first urosternite and glandular $a_{2}$ setae on the first urosternite appendages (Fig. 62).

Plusiocampinae is diverse and widespread in cave areas of Asia with eight genera in Asian caves: Anisuracampa with one cave species in Myanmar and another in soil in China; Plusiocampa with one cave species in the Anatolian peninsula, another in the western Caucasus and numerous cave and soil species limited to the Euro-Mediterranean region; Plutocampa with three species in the Russian Far East and northeast China; Hubeicampa gen. nov. with two species in central China; and five monotypic genera: Vandelicampa Condé, 1955 in the most western part of Asia, Simlacampa Condé, 1956 in northwest India, Turkmenocampa in central Asia, and Whittencampa in southern China. All these genera show important differences in their pretarsal structures, with unclear relationships between them. Pretarsus lateral crests of claws with different sizes and ornamentation are present in all genera except Turkmenicampa, which has a lateral, sharp side-piece on each claw. However, the pretarsus lateral processes vary among the genera: setiform (Plusiocampa), subcylindrical (Whittencampa) or absent (Plutocampa), and laminar in the rest of the genera. The laminar lateral processes are long and narrow (Simlacampa and Anisuracampa), short and spiniform (Hubeicampa gen. nov.), or long, spiniform (Vandelicampa) (Condé 1955, 1956, 1993; Chevrizov 1978; Sendra et al. 2017a, Sendra \& Deharveng 2020, Sendra et al. 2020).

Simlacampa and Anisuracampa have a very similar pretarsus (claws with lateral crests, and laminar and divided lateral processes). The complete pretarsus of Simlacampa was drawn with full details by Condé (1956: figs 1-2), allowing it to be compared with SEM images of Anisuracampa ywangana sp. nov. (Figs 12-15). However, at least two differences separate these genera. Anisuracampa has two or three dorsal macrosetae on the metathoracic femur compared to none in Simlacampa. Also, Anisuracampa has numerous macrosetae on the nota (Fig. 9) and urotergites (medial anterior, lateral anterior, and lateral posterior macrosetae on the meso and metanotum, $4+4-5+5$ posterior macrosetae on the urotergites $\mathrm{V}-$ VII) compared with less macrosetae in Simlacampa (1+1 lateral posterior macrosetae on the mesonotum and none on the metanotum; $2+2$ posterior macrosetae on the urotergite VII). The pretarsus in other genera of Plusiocampinae has some similarities with that of Anisuracampa and Simlacampa, such as 
Cestocampa Condé, 1956; Patrizicampa Condé, 1956 or Vandelicampa, with broad laminar pretarsal lateral processes (Sendra et al. 2017), but closer study needs to be made with SEM or high-quality optical microscopy.

Hubeicampa gen. nov. proposed for Hubeicampa melissa gen. et sp. nov. and Hubeicampa lipsae (Condé 1993) comb. nov. (= Plusiocampa (Dydimocampa) lipsae Condé, 1993), inhabiting caves in Hubei, central China, is characterized by a unique pretarsus with subequal, elbowed claws and lateral crests as in many Plusiocampinae, except that the basal and ventral portions of the claws are covered with numerous, very small spiniform formations that appear pubescent under an optical microscope, and the laminar pretarsal lateral processes, which are completely covered with dense micro-barbs (Figs 36-39). In addition, species of Hubeicampa gen. nov. are characterized by a singular kind of pubescent setae and macrosetae covered with micro-barbs visible under high magnifications (Figs 26-29).

Cave-adapted japygids are taxonomically defined, due to their genetic isolation, and thus their genera are well settled and separated from other taxa (Pagés 1980; Muegge 1992; Sendra et al. 2006b). In continental Asia, cave-adapted species are represented by Kohjapyx lindbergei Pagés, 1962 from a cave in Afghanistan, Burmjapyx inferus (Carpenter, 1932) from Batu Caves in Malaysia (Pagés 1962, 1964) and Mueggejapyx brehieri gen. et sp. nov. from four caves in western Myanmar. These taxa especially differ in cercal shape and distribution patterns of teeth and denticles.

The loss of the medial cercal tooth is the most distinguishing feature of Mueggejapyx gen. nov., which is only shared with three other genera: Psalidojapyx Pagés, 2000 with two species from Borneo; Rectojapyx Pagés, 1953 with one species from Europe and Rossjapyx Smith, 1962 with two species from Chile, all of which are soil-dwelling (Pagés 1953, 2000; Smith 1962). Mueggejapyx gen. nov. differs in the unique shape of its cerci, which are strong and well developed, elongated and rectilinear, becoming curved subapically. Each cercus has exterior dorsal and ventral carinae and very short rows of small basal denticles preceded by a basal notch on the right cercus and a round tooth on the left cercus (Figs 91-95). Another important feature of Mueggejapyx gen. nov. is the presence of mostly shorter lateral subcoxal organs occupying less than $1 / 3$ of the interstyle width with smaller glandular setae. Cave-adapted features of $M$. brehieri gen. et sp. nov. include extra placoid sensilla on the antennomeres from the middle of the antennae to the apex, with numerous placoid sensilla on the apical antennomere (Figs 65-66), and a substantial lengthening of thoracic segments and body in general (Figs 71, 75).

\section{Troglomorphy}

The handful of cave-adapted campodeid species already known in Asia show highly adapted features to cave ecosystems. In campodeids, the longest bodies with elongated segments, particularly of the thorax, belong to Pacificampa daudarabochi Sendra, 2018 and Hubeicampa melissa gen. et sp. nov., being more than one centimetre in length. In all Asian cave species, the antennae, legs and cerci are elongated: metathoracic legs reach or overpass the end of the abdomen; the antennae are as long as or longer than the body length; and the cerci can be twice the body size in some species (e.g., Whittencampa troglobia Sendra \& Deharveng, 2020) (Sendra \& Deharveng 2020). The elongation of appendages in cave-adapted species is due to the increase in article length and/or more numerous antennomeres and cercal articles (Sendra et al. 2017b). The lengths of the middle antennomere are twice that of the width and the length of the apical antennomere is four times that of the width in species of Hubeicampa gen. nov., P. daudarabochi and W. troglobia. However, in cave-adapted species of Lepidocampinae, the antennomere length and width are equal but the antennomeres increase in number (Sendra et al. 2017b). The antennomeres and cercal articles in Asian cave-adapted species can reach very high numbers, e.g., in W. troglobia with 54 antennomeres, the highest in Plusiocampinae (Sendra \& Deharveng 2020). Sensory organs may have unique shapes in the macrosetae and setae with dense and uniformly distributed barbs in H. melissa gen. et sp. nov., visible at high magnifications (Figs 26-29). Olfactory receptors in central 
and eastern Asian species differ from the concentric folds found in Euro-Mediterranean cave-species in Plusiocampinae and Campodeinae (Sendra et al. 2020; Sendra \& Reboleira 2020): with a networkshaped structure (H. melissa gen. et sp. nov.) (Figs 20-21, 23); oviform and tree-shaped (Turkmenocampa mirabilis Sendra \& Stoev, 2017) or caliciform shape with folds in radial expansions from a central axis (P. daidarabotchi) (Sendra et al. 2017, 2018). The mechanoreceptor setae reach a unique shape with tiny expansions called micro-barbs in the highly cave-adapted $H$. melissa gen. et sp. nov., which are not seen in other campodeids (Figs 26-29).

The pretarsal structure adaptations in Plusiocampinae show an important variation range, apparently correlated with cave-habitat. Cave-dwelling species of Plusiocampa have larger claws and bigger lateral crests than their soil relatives (Condé 1956; Sendra et al. 2020). The claws have lateral crests, except for T. mirabilis which has two sharp side-piece expansions instead. The laminar lateral processes of Anisuracampa, Hubeicampa gen. nov., and Turkmenocampa each have narrow laminar expansions (Figs 12-15), very small barbs (Figs 36-39), or long barbs (Sendra et al. 2017a) with more or less apical enlargements that seem to have sticky properties, allowing those diplurans to walk on smooth surfaces (e.g., speleothems).

The three exclusively Asian cave-adapted japygids show different stages of troglomorphy. Burmajapyx inferus shows no elongation in body or appendages, and although it has extra placoid sensilla on the medial and distal antennomeres, it does not have extra sensilla on the apical antennomere. Kohjapyx lindbergi Pagés, 1962 shows a moderate elongation in body and appendages and has extra placoid sensilla on the apical antennomere. Mueggejapyx brehieri gen. et sp. nov. is noticeably elongated (Figs 2,71,75), especially in the thoracic segments, and has extra placoid sensilla on the medial, distal, and apical antennomeres (Figs 65-66).

\section{Diversity and distribution}

Although there are several studies dealing with local Asian dipluran faunas (e.g., Silvestri 1931, 1948; Chou 1983, 1984; Pagés 1984, 2002; Condé 1990; Sendra et al. 2006a, 2010; among others), the Asian diplurans have never been the subject of a comprehensive work. A total of 197 species of diplurans has been described or cited from soil and cave habitats from 508 localities, mostly distributed throughout western and eastern or southeastern Asia. The 21 known Asian cave-adapted dipluran species follow this same general distribution pattern, although they are unavoidably restricted to the vast karst regions of Asia (Figs 98-99; Supp. file 1). Nevertheless, cave diplurans have not been found in desert zones, probably due to the lack of infiltration of organic matter into cave ecosystems (Sendra \& Reboleira 2014) (Figs 98-99). Furthermore, diplurans cannot enter hypogenic cave systems, although they can thrive in there after the erosion of the confining rock layers (Klimchouk 2007; Sendra et al. 2014; Jimenez-Valverde et al. 2017) (Figs 98-99). A very important historical factor that has conditioned the current distribution of cave diplurans is the former extension of glacial and permafrost areas during the Last Glacial Maximum (Fig. 98). These frozen conditions presumably eliminated terrestrial cave animals from vast geographical regions that have not yet been recolonized, something that has been shown for other taxonomic groups with limited dispersal abilities (e.g., Svenning \& Skov 2007). Finally, although there are many vast karst areas in China without records, these are covered, even if in a patched way, by permafrost at present, so the presence of cave-adapted diplurans seems unlikely (Fig. 99). In contrast, there are extensive karstic areas in southeast China that have the potential to harbour new species to science (Figs 98-99).

The different taxonomic groups of Asian cave-adapted diplurans have an unequal representation in the different Asian regions. While japygids seem to barely colonize cave-ecosystems, with three currently known species belonging to three genera, campodeids have a much larger presence in caves, with 18 already described species belonging to 10 genera from western to eastern Asian regions. Within 

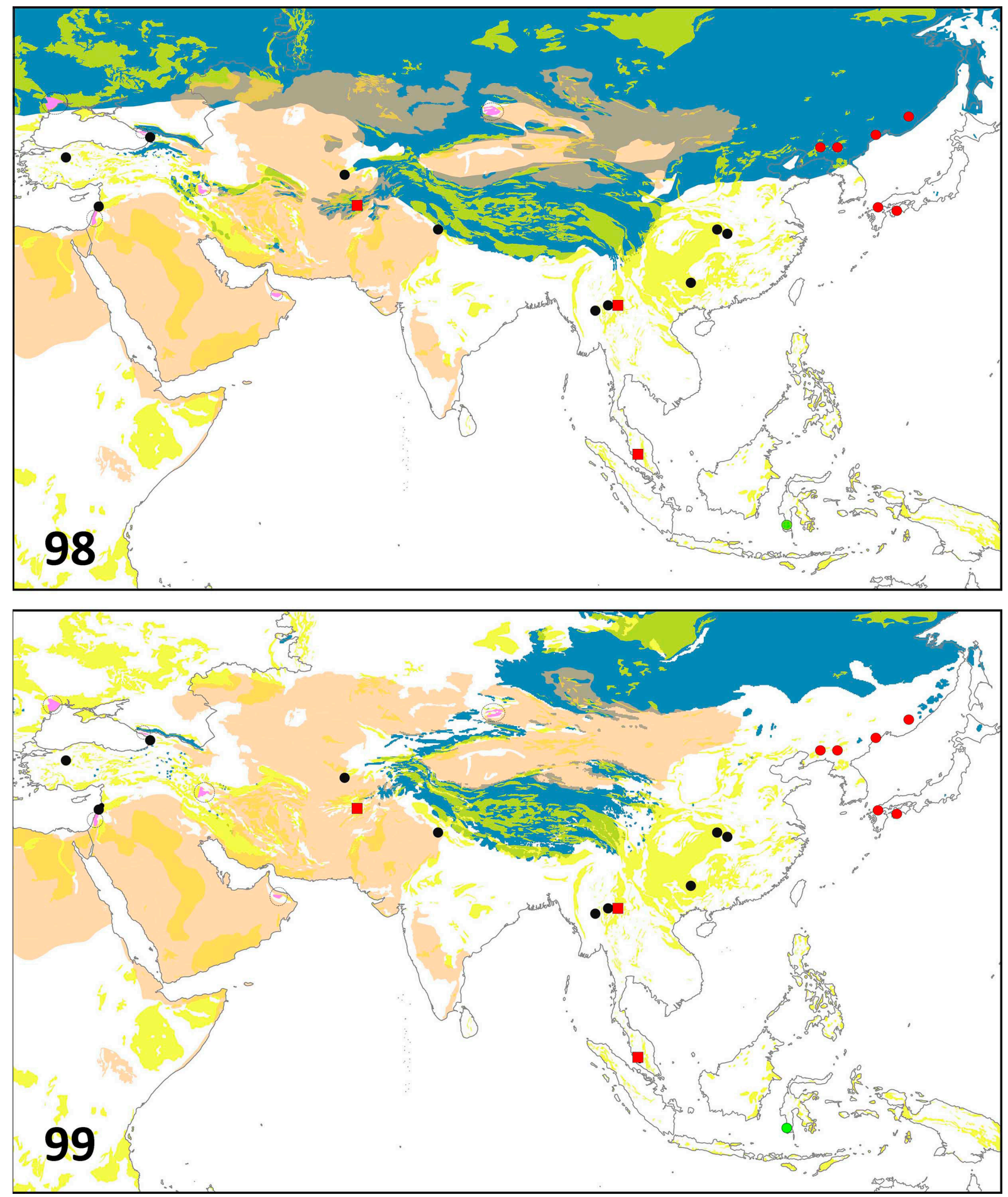

Figure 98-99. Distribution maps of cave-adapted diplurans in Asia: Campodeinae Condé, 1956 (red circles), Plusiocampinae Paclt, 1957 (black circles), Lepidocampinae Condé, 1956 (brown circles), Japygidae Haliday, 1864 (red squares). In yellow: karst areas (source: Chen et al. 2017). In orange: deserts (source: Olson \& Dinerstein 2002). In violet, encircled by discontinued line: hypogean karst systems (source: Klimchouk 2007). 98. In blue: ice cover and permafrost extent during the Last Glacial Maximum (sources: Ehlers et al. 2011; Lindgren et al. 2016). 99. In blue: areas covered with either continuous or patched permafrost at present (source: Brown et al. 2002). 
campodeids, three subfamilies are present in Asia. Lepidocampinae has twelve species in Asia and one cave-adapted species, L. hypogaea, known from seven caves in Sulawesi. Campodeinae has 52 soil species all across Asia, but only one genus Pacificampa is present in caves, three species in the Far East of Russia and northeast of China and two in Japan. It is Plusiocampinae, which has the lion's share of the Asian cave-dipluran diversity with eight genera and 12 species present in all Asian regions, but with only three species in soil habitats. Among cave Plusiocampinae, Plusiocampa and Vandelicampa occupy caves in western Asia in the Western Caucasus, Turkey and Lebanon; Turkmenocampa is found in a single cave of Central Asia in Turkmenistan; Simlacampa is known from southern Asia and was found in three caves of Penjab, India; Anisuracampa is known from a single cave in southeast Myanmar; whereas Hubeicampa gen. nov. and Whittencampa are found in eastern Asia, from Central to South China.

Asian cave-ecosystems have recently shown their remarkable biodiversity and extraordinary cave-adapted characteristics in many zoological groups, diplurans included (Deharveng et al. 2008; Golovatch 2015; Tian et al. 2016; Sendra et al. 2017a, 2018; Sendra \& Deharveng 2020), and the present contribution highlights the relevance of all cave-adapted diplurans in all regions from Asia.

\section{Acknowledgements}

The collection of specimens in caves of northeastern China has been possible thanks to Prof. Wu Donghui (NEIGAE, Changchun). We are grateful to Wu Donghui, Anne Bedos and Louis Deharveng (Muséum national d'histoire naturelle, Paris) who provided us with the cave specimens from Liaoning and Jilin Provinces (China) for study. Special thanks also to Sergei Golovatch (Russian Academy of Sciences, Moscow) for making accessible the type material of ZMMU and the kind translation of the descriptions of B.P. Chevrizov. We are grateful to Fauna \& Flora Myanmar for providing material from Myanmar. Many thanks to the SEM facility of the Universitat de València, especially to Enrique Navarro, Pilar Gómez and Rafael Benito, as well as to Lucia Maltez and Katie Marzen for the English revision of the text. We are grateful to the authors of the World Karst Aquifer Mapping project for providing the GIS data used in Figures 98-99. A.J.-V. was supported by the Spanish Ramón y Cajal Program (RYC-201314441), which is financed by the Spanish Ministry of Science, Innovation and Universities. Special thanks to the anonymous referee for his effort and useful comments on the manuscript.

\section{References}

Bareth C. \& Condé B. 1981. Nouveaux Campodéidés de grottes d'Espagne. Revue suisse de Zoologie 88 (3): 775-786. https://doi.org/10.5962/bhl.part.82407

Bareth C. \& Pagés J. 1994. Diplura. In: Juberthie C.. \& Decu V. Encyclopaedia Biospeologica. Vol. I: 277-283. Société de Biospéologie.

Barlet J. \& Carpentier F. 1962. Le thorax des Japygides. Bulletin et Annales de la Société royale d'Entomologie de Belgique 8: 95-127.

Brown J., Ferrians O., Heginbottom J.A. \& Melnikov E. 2002. Circum-Arctic Map of Permafrost and Ground-Ice Conditions, Version 2. Boulder, Colorado USA. NSIDC: National Snow and Ice Data Center.

Chen Z., Auler A., Bakalowicz M., Drew D., Griger F., Hartmann J., Jiang G., Moosdorf N., Richts A., Stevanovic Z., Veni G. \& Goldscheider N. 2017. The world karst aquifer mapping project: concept, mapping procedure and map of Europe. Hydrogeology Journal 25: 771-785.

https://doi.org/10.1007/s10040-016-1519-3

Chevrizov B.P. 1978. Two new genera of the Family Campodeidae from the Far East Caves. Zoologichesky Zhurnal 57 (2): 197-205. 
Chou I. 1983. Japygidae (V). Entomotaxonomia V (4): 327-358.

Chou I. 1984. Studo de Japigedoj (VI) (Dipluroj: Japygedoj). Entomotaxonomia VI (1): 55-58.

Condé B. 1955. Mission Henri Coiffait au Liban (1951). 4. Protoures et Diploures Campodéidés. Biospeologica LXXV: 397-412.

Condé B. 1956. Un Campodéidé troglobie de l'Inde. Notes biospéologiques 11: 101-105.

Condé B. 1990. Diploures Campodéidés de Bornéo. Revue suisse de Zoologie 97 (2): 465-475.

https://doi.org/10.5962/bhl.part.79749

Condé B. 1992. Campodéidés des grottes des Célebes (Insectes, Diploures). Mémoires biospéologie XIX: $155-158$.

Condé B. 1993. Premiers Campodeidae cavernicoles de China, comme exemple de l'évolution souterraine de la Famille (Diplura). Revue suisse de Zoologie 100 (4): 823-828.

Available from https://www.biodiversitylibrary.org/page/41223963 [accessed 19 Nov. 2020].

Deharveng L. \& Bedos A. 2018. Diversity of terrestrial invertebrates in subterranean habitats. In: Moldovan O.T., Kováč L. \& Halse S. (eds) Cave Ecology: 107-172. Springer, Cham. https://doi.org/10.1007/978-3-319-98852-8_7

Deharveng L., Bréhier F., Bedos A., Tian M.Y., Li Y.B., Zhang F., Quin W.G. \& Tan X.F. 2008. Mulun and surrounding karsts (Guangxi) host the richest cave fauna of China. Subterranean Biology 6: 75-79.

Denis J.R. 1949. Ordre des Diploures. In: P.P. Grassé (ed.) Traité de Zoologie IX: 160-185. Masson, Paris.

Deuve T. 2017. Découverte du premier Carabique troglobie de Birmanie et descriptions de deux nouveaux Lanxangaphaenops du Laos (Coleoptera, Caraboidea, Trechidae). Bulletin de la Société entomologique de France 122 (1): 97-104.

Ehlers J., Gibbard P.L. \& Hughes P.D. (eds) 2011. Quaternary Glaciations - Extent and Chronology. Vol. 15. Elsevier.

Ferguson L.M. 1997. A report on a new species of Pacificampa (Diplura: Campodeidae) from a cave in China and a comparison of some North America genera to Pacificampa and Plutocampa previously only known from the Far East of Russia. Proceedings of the $12^{\text {th }}$ International Congress of Speleology La Chaux-de-Fonds, Neuchâtel, Switzerland, August 10-17, Vol. 3:315-317. Société Suisse de Spéléologie, Neuchâtel.

Golovatch S.I. 2015. Cave Diplopoda of southern China with reference to millipede diversity in Southeast Asia. Zookeys 510: 79-94. https://doi.org/10.3897/zookeys.510.8640

Grismer L.L., Perry L., Wood Jr., Myint Kyaw T., Thaw Z., Evan S.H., Quah M.L., Murdoch M.S., Grismer A.L., Htet K. \& Ngwe L. 2017. Twelve new species of Cytodactylus Gray (Squamata: Gekkonidae) from isolated limestone habitats in east-central and southern Myanmar demonstrate high localized diversity and unprecedented microendemism. Zoological Journal of the Linnean Society 182: 862-959. https://doi.org/10.1093/zoolinnean/zlx057

Jiménez-Valverde A., Sendra A., Garay P. \& Reboleira A.S.P.S. 2017. Energy and speleogenesis: Key determinants of terrestrial species richness in caves. Ecology and Evolution 7 (23): 10207-10215. https://doi.org/10.1002/ece3.3558

Juberthie C. \& Decu V. 2001. Encyclopaedia Biospeologica, III: 1374-2296. Société de Biospéologie, Moulis, France and Bucarest. 
Klimchouk A. 2007. Hypogene Speleogenesis: Hydrogeological and Morphogenetic Perspective. Special Paper 1. National Cave and Karst Research, Carlsbad, NM.

Lindgren A., Hugelius G., Kuhry P., Christensen T.R. \& Vandenberghe J. 2016. GIS-based maps and area estimates of northern hemisphere permafrost extent during the Last Glacial Maximum. Permafrost and Periglacial Processes 27: 6-16. https://doi.org/10.1002/ppp.1851

Lips B., Faverjon M., Routhieau V., Schalk P. \& Lips J. 2009. Rapport de la $8^{\text {ième }}$ expédition spéléologique en Chine, provinces de l'Hubei et du Sichuan. Aventures karstiques lointaines \& Institut de technologie de Chengdu. Spéléologie au pays de l'Homme sauvage 8: 1-112.

Ma L. \& Zhao Y. 2012. Cavefish of China. In: Culver D.C. \& White W.B. (eds) Encyclopedia of Caves, $2^{\text {nd }}$ ed.: 107-125. Academic Press and Elsevier.

Muegge M.A. 1992. New species of cavernicolous japygid (Diplura: Japygidae) from Texas. Annals of the Entomological Society of America 85 (4): 406-412. https://doi.org/10.1093/aesa/85.4.406

Muegge M.A. \& Bernard E.C. 1990. Two new species of Metajapyx (Diplura: Japygidae) from Tennessee. Proceedings of the Entomological Society of Washington 92 (4): 793-801.

Ng P.K.L. \& Whitten A.J. 2017. On a new species of Shanphusa Yeo \& Ng, 2007 (Brachyura, Potamoidae, Potamidae), from a cave in central Myanmar. Crustaceana 90 (2) 235-245.

https://doi.org/10.1163/15685403-00003646

Olson D. \& Dinerstein E. 2002. The Global 200: priority ecoregions for global conservation. Annals of the Missouri Botanical Garden 89: 199-224. https://doi.org/10.2307/3298564

Pagés J. 1953. Japyginae (Japygidae, Insecta, Diplura) de la Yougoslavie et des régions limitrophes. Bulletin du Muséum d'Histoire naturelle du Pays serbe Série B (5-6): 235-264.

Pagés J. 1962. Japygidae (Insecta, Diplura) de l'Afghanistan II. (Contribution à l'étude de la Fauna de l'Afghanistan. 58). Comptes Rendus $86^{e}$ Congrès des Sociétés savantes (Montpellier, 1961): 735-750.

Pagés J. 1964. Remarques sur les Japygidae signales dans le domaine souterrain. International Journal of Speleology 1 (1-2): 191-201.

Pagés J. 1977. Dicellurata Genavensia III. Japygidés du Sud-Est asiatique $n^{\circ} 1$. Revue suisse de Zoologie 84 (3): 687-698. https://doi.org/10.5962/bhl.part.91418

Pagés J. 1980. Dicellurata Genavensia VII. Japygidés d'Europe et du bassin méditerranéen ${ }^{\circ} 2$. Revue suisse de Zoologie 87 (2): 637-645. https://doi.org/10.5962/bhl.part.85537

Pagés J. 1984. Dicellurata Genavensia XIII. Japygidés du Sud-Est asiatique. № 4. Revue suisse de Zoologie 91 (1-2): 329-368. https://doi.org/10.5962/bhl.part.81883

Pagés J. 2000. Japygidés du Sud-Est asiatique $\mathrm{n}^{\circ}$ 9. Dicellurata Genavensia XXIV. Revue suisse de Zoologie 107 (3-4): 737-764. https://doi.org/10.5962/bhl.part.80146

Pagés J. 2002. Japygidés du Sud-Est asiatique $\mathrm{n}^{\circ}$ 10: Dicellurata Genavensia XXVI. Revue suisse de Zoologie 109 (3): 653-677. https://doi.org/10.5962/bhl.part.79615

Sendra A. 2015. Clase Entognatha. Orden Diplura. Revista IDE@ 35: 1-11.

Available from http://sea-entomologia.org/IDE@/revista_35.pdf [accessed 11 Dec. 2020].

Sendra A. \& Deharveng L. 2020. Whittencampa troglobia, a new genus and species of troglomorphic Plusiocampinae from China (Diplura: Campodeidae). Raffles Bulletin of Zoology Supplement 35: 68-77.

Sendra A. \& Reboleira A.S.P.S. 2014. La extensión y los límites de la fauna en los hábitats subterráneos. Boletín Asociación española de Entomología 38 (3-4): 203-224. 
Sendra A. \& Reboleira A.S.P.S. 2020. Euro-Mediterranean fauna of Campodeinae (Campodeidae, Diplura). European Journal of Taxonomy 728: 1-130. https://doi.org/10.5852/ejt.2020.728.1181

Sendra A., Satar A. \& Montagud S. 2006a. Première contribution à la faune de Diploures Campodéidés de la Péninsula d'Anatolie, Turquie (Diplura: Campodeidae). Revue suisse de Zoologie 113 (3): 693-709. https://doi.org/10.5962/bhl.part.80368

Sendra A., Ortuño V.M., Moreno A., Montagud S. \& Teruel S. 2006b. Gollumjapyx smeagol gen. n., sp. n., an enigmatic hypogean japygid (Diplura: Japygidae) from the eastern Iberian Peninsula. Zootaxa 1372: 35-52. https://doi.org/10.11646/zootaxa.1372.1.4

Sendra A., Teruel S., Satar A., Tusun S. \& Özbay C. 2010. New species, new records, and distribution of Campodeidae (Diplura) in Anatolia. Zootaxa 2639: 40-52. https://doi.org/10.11646/zootaxa.2639.1.4

Sendra A., Garay P., Ortuño V.M., Gilgado J.D., Teruel S. \& Reboleira A.S.P.S. 2014. Hypogenic versus epigenic subterranean ecosystem: lessons from eastern Iberian Peninsula. International Journal of Speleology 43 (3): 253-264. https://doi.org/10.5038/1827-806X.43.3.2

Sendra A., Sket B. \& Stoev P. 2017a. A striking new genus and species of troglobitic Campodeidae (Diplura) from Central Asia. Subterranean Biology 23: 47-68. https://doi.org/10.3897/subtbiol.23.14631

Sendra A., Jiménez-Valverde A., Rochatc J., Legrosc V., Gasnierc S. \& Cazanove G. 2017b. A new and remarkable troglobitic Lepidocampa Oudemans, 1890 species from La Réunion Island, with a discussion on troglobiomorphic adaptations in campodeids (Diplura). Zoologischer Anzeiger 266: 95-104.

https://doi.org/10.1016/j.jcz.2016.11.005

Sendra A., Yoshizawa K. \& Ferreira R.L. 2018. New oversize troglobitic species of Campodeidae in Japan (Diplura). Subterranean Biology 27: 53-73. https://doi.org/10.3897/subtbiol.27.28575

Sendra A., Antić D., Barranco P., Borko Š., Christian E., Delić T., Fadrique F., Faille A., Galli L., Gasparo F., Georgiev D., Giachino P.M., Kováč L., Lukić M., Marcia P., Miculinić K., Nicolosi G., Palero F., Paragamian K., Pérez T., Polak S., Prieto C.E., Turbanov I., Vailati D. \& Reboleira A.S.P.S. 2020. Flourishing in subterranean ecosystems: Euro-Mediterranean Plusiocampinae and tachycampoids (Diplura, Campodeidae). European Journal of Taxonomy 591: 1-138.

https://doi.org/10.5852/ejt.2020.591

Silvestri F. 1931. Campodeidae (Insecta Thysanura) dell'estremo Oriente. Bolletino del Laboratorio d'Entomologia agraria in Portici XXV: 286-320.

Silvestri F. 1948. Contributo alla conoscenza degli Japygidae (Insecta Diplura). Società Italana delle Scienze detta Accademia dei XL Series III (XXVII): 3-115.

Smith L.M. 1962. Japygidae of South America, 3. Japygidae of Chile. Proceedings of the Biological Society of Washington 75: 273-292.

Svenning J.C. \& Skov F. 2007. Could the tree diversity pattern in Europe be generated by postglacial dispersal limitation? Ecological Letters 10: 453-460. https://doi.org/10.1111/j.1461-0248.2007.01038.x

Taiti S. \& Montesanto G. 2020. Troglobiotic terrestrial isopods from Myanmar, with descriptions of a new genus and three new species (Crustacea, Oniscidea). In: Kottelat M., Deharveng L. \& Ng P.K.L. (eds) Anthony J. Whitten (1953-2017) Memorial Issue. Raffles Bulletin of Zoology Supplement 35: 109-122.

Tian M.Y., Huang S.B., Wang X.H. \& Tang M.R. 2016. Contribution to the knowledge of subterranean trechine beetles in Southern China's karsts: five new genera (Insecta, Coleoptera, Carabidae, Trechinae). ZooKeys 564: 121-156. https://doi.org/10.3897/zookeys.564.6819 
Xie R. \& Yang Y. 1991. Description of two new genera and three new species of Campodeidae in China (Diplura). Contribution Shanghai Institute of Entomology 10: 95-102.

Manuscript received: 29 April 2020

Manuscript accepted: 24 September 2020

Published on: 5 January 2021

Topic editor: Nesrine Akkari

Desk editor: Kristiaan Hoedemakers

Printed versions of all papers are also deposited in the libraries of the institutes that are members of the EJT consortium: Muséum national d'histoire naturelle, Paris, France; Meise Botanic Garden, Belgium; Royal Museum for Central Africa, Tervuren, Belgium; Royal Belgian Institute of Natural Sciences, Brussels, Belgium; Natural History Museum of Denmark, Copenhagen, Denmark; Naturalis Biodiversity Center, Leiden, the Netherlands; Museo Nacional de Ciencias Naturales-CSIC, Madrid, Spain; Real Jardín Botánico de Madrid CSIC, Spain; Zoological Research Museum Alexander Koenig, Bonn, Germany; National Museum, Prague, Czech Republic.

\section{Supplementary material}

Supp. file 1: Table of cave-adapted species and their localities in Asia. https://doi.org/10.5852/ejt.2021.731.1199.3387

Supp. file 2: Anisuracampa ywangana Sendra \& Komericki sp. nov. in its type locality Win Twin Cave (Shan State, Ywangan, Myanmar). https://doi.org/10.5852/ejt.2021.731.1199.3389

Supp. file 3: Hubeicampa melissa Sendra \& Lips gen. et sp. nov. in Grotte du $8^{\text {ième }}$ Ciel (Baxian Dong. Hubei, China). https://doi.org/10.5852/ejt.2021.731.1199.3391 